LBNL - 62806

\title{
World Best Practice Energy Intensity Values for Selected Industrial Sectors
}

\section{Ernst Worrell, Lynn Price, Maarten Neelis,}

Christina Galitsky, Zhou Nan

June 2007

Prepared with the support of the China Sustainable Energy Program of the Energy Foundation through the Department of Energy under contract No. DE-AC02-05CH11231 
DISCLAIMER OF LIABILITY: Neither the United States Government nor the University of California nor any of their employees, makes any warranty, express or implied, including the warranties of fitness for a particular purpose, or assumes any legal liability or responsibility for the accuracy, completeness, or usefulness of any information disclosed herein.

Published in the United States by Environmental Energy Technologies Division

Lawrence Berkeley National Laboratory

One Cyclotron Road, MS 90R4000

Berkeley, CA 94720 USA 


\begin{abstract}
"World best practice" energy intensity values, representing the most energy-efficient processes that are in commercial use in at least one location worldwide, are provided for the production of iron and steel, aluminium, cement, pulp and paper, ammonia, and ethylene. Energy intensity is expressed in energy use per physical unit of output for each of these commodities; most commonly these are expressed in metric tonnes (t). The energy intensity values are provided by major energy-consuming processes for each industrial sector to allow comparisons at the process level. Energy values are provided for final energy, defined as the energy used at the production facility as well as for primary energy, defined as the energy used at the production facility as well as the energy used to produce the electricity consumed at the facility. The "best practice" figures for energy consumption provided in this report should be considered as indicative, as these may depend strongly on the material inputs.
\end{abstract}

Key words: energy intensity, industry, steel, aluminium, cement, paper, ammonia, ethylene 


\section{Table of Contents}

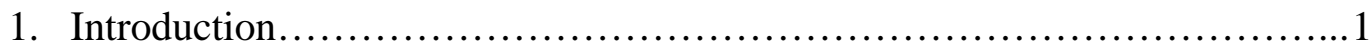

2. World Best Practice Energy Intensity Values.............................. 5

2.1. Iron and Steel........................................................... 5

2.1.1 Blast Furnace - Basic Oxygen Furnace Route........................ 6

2.1.2 Smelt Reduction - Basic Oxygen Furnace............................. 10

2.1.3 Direct Reduced Iron - Electric Arc Furnace....................... 13

2.1.4 Electric Arc Furnace........................................... 15

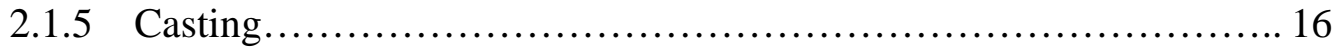

2.1.6 Rolling and Finishing.............................................

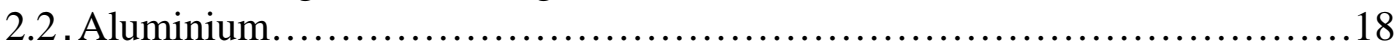

2.2.1 Alumina Production.................................................... 19

2.2.2 Anode Manufacture............................................... 19

2.2.3 Aluminium Smelting (Electrolysis) ............................... 20

2.2.4 Ingot Casting...................................................... 20

2.2.5 Secondary Aluminium Production..................................21

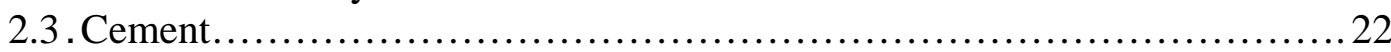

2.3.1 Raw Materials and Fuel Preparation.................................22

2.3.2 Clinker Production............................................... 29

2.3.3 Additive Preparation............................................. 29

2.3.4 Finish Grinding................................................ 29

2.3.5 Other Production Energy .............................................. 30

2.4. Pulp and Paper........................................................... 31

2.4.1 Non-Wood Pulping..................................................

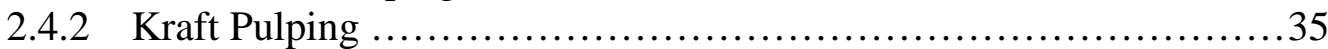

2.4.3 Sulfite Pulping................................................... 35

2.4.4 Mechanical Pulping................................................ 35

2.4.5 Fiber Recovery................................................. 36

2.4.6 Papermaking........................................................ 36

2.4.7 Integrated Pulp and Paper Mills.....................................36

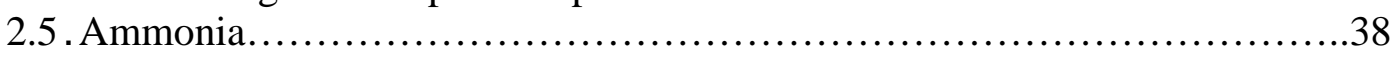

2.5.1 Natural Gas Steam Reforming..................................... 38

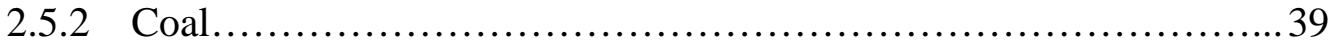

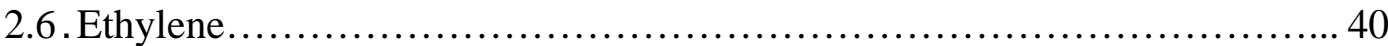

2.6.1 Naphtha and Ethane ............................................ 40

2.6.2 Other Feedstocks and Emerging Technologies......................43

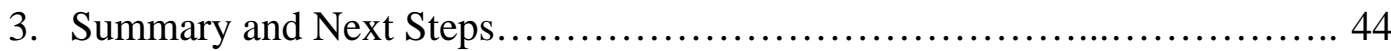

4. Acknowledgments.........................................................44 



\section{Introduction}

This report provides information on world best practice energy intensity values for production of iron and steel, aluminium, cement, pulp and paper, ammonia, and ethylene. "World best practice" values represent the most energy-efficient processes that are in commercial use in at least one location worldwide. ${ }^{1}$

These values are expressed in energy use per physical unit of output for each of these commodities; most commonly these are expressed in metric tonnes (t). Energy values are provided in both système international (SI) units (joules) and in kilograms of coal equivalent (kgce), a common unit in China. ${ }^{2}$

Energy values are provided for final energy, defined as the energy used at the production facility as well as for primary energy, defined as the energy used at the production facility as well as the energy used to produce the electricity consumed at the facility. For primary energy values, the losses associated with conversion of fuels into electricity along with the losses associated with transmission and distribution of the electricity are included. It is assumed that these losses are 67\%. The energy values referenced in the text of this document are provided for final energy only; primary energy values can be found in the tables.

Table 1.1 provides a summary of the world best practice final energy intensity values for the sectors covered in this report. Table 1.2 provides a summary of the world best practice primary energy intensity values. Details regarding the calculation of these values and references are provided in the following sections.

\footnotetext{
${ }^{1}$ While this report describes best practices in energy efficiency for key processes, the integration of these individual technologies is key to obtain the full benefits of these technologies. For example, combined heat and power would increase the efficiency of steam supply for the described processes, while by-product energy flows may also be used more efficiently by implementing more efficient technologies (e.g. use of blast-furnace gas in a combined cycle instead of a boiler).

2 In April 2006, China's central government launched the Top-1000 Enterprises Energy-Efficiency Program (Top-1000 program), the goal of which is to improve industrial energy efficiency by targeting China's 1000 highest energy-consuming enterprises. These enterprises currently account for approximately $50 \%$ of total industrial sector energy consumption and 30\% of total energy consumption in China. During the summer of 2006, energy-saving agreements with targets for 2010 were signed with all Top-1000 enterprises. The Top-1000 enterprises are from the iron and steel, petroleum and petrochemical, chemical, non-ferrous metal, building materials, pulp and paper, electricity production, coal mining, and textile industries. Chinese government officials have expressed a desire to understand how Chinese industrial enterprises compare to international best practice.
} 
Table 1.1. Summary of World Best Practice Final Energy Intensity Values for Selected Industrial Sectors

\begin{tabular}{|c|c|c|c|c|}
\hline & & Unit & $\mathbf{G J} / \mathbf{t}$ & kgce/t \\
\hline \multicolumn{5}{|l|}{ Iron and Steel } \\
\hline & Blast Furnace - Basic Oxygen Furnace - Thin Slab Casting & t steel & 14.8 & 504.5 \\
\hline & Smelt Reduction - Basic Oxygen Furnace - Thin Slab Casting & t steel & 17.8 & 606.4 \\
\hline & Direct Reduced Iron - Electric Arc Furnace - Thin Slab Casting & t steel & 16.9 & 576.2 \\
\hline & Scrap - Electric Arc Furnace - Thin Slab Casting & t steel & 2.6 & 87.5 \\
\hline \multicolumn{5}{|l|}{ Aluminium } \\
\hline & Primary Aluminium & $\mathrm{t}$ aluminium & 70.6 & 2411 \\
\hline & Secondary Aluminium & $\mathrm{t}$ aluminium & 2.5 & 85 \\
\hline \multicolumn{5}{|l|}{ Cement } \\
\hline & Portland Cement & t cement & 3.0 & 101 \\
\hline & Fly Ash Cement & t cement & 2.5 & 83 \\
\hline & Blast Furnace Slag Cement & t cement & 1.9 & 65 \\
\hline \multicolumn{5}{|l|}{ Pulp } \\
\hline & Non-wood Market Pulp & air dried t & 7.7 & 264 \\
\hline & Wood Kraft Pulp & air dried t & 11.1 & 380 \\
\hline & Wood Sulfite Pulp & air dried t & 18.5 & 632 \\
\hline & Wood Thermo-mechanical Pulp & air dried t & 6.6 & 224 \\
\hline & Recovered Paper Pulp & air dried t & 1.5 & 51 \\
\hline \multicolumn{5}{|l|}{ Paper } \\
\hline & Uncoated Fine Paper & air dried t & 9.0 & 307 \\
\hline & Coated Fine Paper & air dried t & 10.4 & 355 \\
\hline & Newsprint & air dried t & 7.2 & 244 \\
\hline & Board & air dried t & 9.6 & 327 \\
\hline & Kraftliner & air dried t & 7.8 & 267 \\
\hline & Tissue & air dried t & 10.5 & 358 \\
\hline \multicolumn{5}{|l|}{ Pulp and Paper } \\
\hline & Bleached Uncoated Fine & air dried t & 18.3 & 625 \\
\hline & Krafliner (unbleached)/Bag Paper & air dried t & 17.6 & 601 \\
\hline & Bleached Coated Fine & air dried t & 22.4 & 765 \\
\hline & Bleached Uncoated Fine & air dried t & 22.3 & 762 \\
\hline & Newsprint & air dried t & 6.6 & 226 \\
\hline & Magazine Paper & air dried t & 7.3 & 248 \\
\hline & Board & air dried $\mathrm{t}$ & 11.8 & 402 \\
\hline & Recovered Paper Board & air dried t & 11.2 & 384 \\
\hline & Recovered Paper Newsprint & air dried t & 7.6 & 259 \\
\hline & Recovered Paper Tissue & air dried t & 11.3 & 386 \\
\hline \multicolumn{5}{|l|}{ Ammonia } \\
\hline & Natural Gas Feedstock (Steam Reforming) & $\mathrm{t}$ ammonia & 28 & 956 \\
\hline & Coal Feedstock & $\mathrm{t}$ ammonia & 34.8 & 1188 \\
\hline \multicolumn{5}{|l|}{ Ethylene } \\
\hline & Ethane Cracking & $\begin{array}{l}\text { t high value } \\
\text { chemicals }\end{array}$ & 12.5 & 427 \\
\hline & Naphtha Cracking & $\begin{array}{l}\text { t high value } \\
\text { chemicals }\end{array}$ & 11 & 409 \\
\hline
\end{tabular}


Table 1.2. Summary of World Best Practice Primary Energy Intensity Values for Selected Industrial Sectors

\begin{tabular}{|c|c|c|c|c|}
\hline & & Unit & $\mathbf{G J} / \mathbf{t}$ & kgce/t \\
\hline \multicolumn{5}{|l|}{ Iron and Steel } \\
\hline & Blast Furnace - Basic Oxygen Furnace - Thin Slab Casting & t steel & 16.3 & 555.1 \\
\hline & Smelt Reduction - Basic Oxygen Furnace - Thin Slab Casting & t steel & 19.2 & 656.8 \\
\hline & Direct Reduced Iron - Electric Arc Furnace - Thin Slab Casting & t steel & 18.6 & 635.8 \\
\hline & Scrap - Electric Arc Furnace - Thin Slab Casting & t steel & 6.0 & 205.1 \\
\hline \multicolumn{5}{|l|}{ Aluminium } \\
\hline & Primary Aluminium & $\mathrm{t}$ aluminium & 174 & 5940 \\
\hline & Secondary Aluminium & $\mathrm{t}$ aluminium & 7.6 & 259 \\
\hline \multicolumn{5}{|l|}{ Cement } \\
\hline & Portland Cement & t cement & 3.5 & 120 \\
\hline & Fly Ash Cement & t cement & 3.3 & 102 \\
\hline & Blast Furnace Slag Cement & t cement & 2.7 & 90 \\
\hline \multicolumn{5}{|l|}{ Pulp } \\
\hline & Non-wood Market Pulp & air dried t & 10.7 & 364 \\
\hline & Wood Kraft Pulp & air dried t & 11.0 & 377 \\
\hline & Wood Sulfite Pulp & air dried t & 23.6 & 807 \\
\hline & Wood Thermo-mechanical Pulp & air dried t & 22.6 & 770 \\
\hline & Recovered Paper Pulp & air dried t & 3.9 & 133 \\
\hline \multicolumn{5}{|l|}{ Paper } \\
\hline & Uncoated Fine Paper & air dried t & 13.7 & 467 \\
\hline & Coated Fine Paper & air dried t & 16.3 & 558 \\
\hline & Newsprint & air dried t & 11.3 & 386 \\
\hline & Board & air dried t & 15.4 & 527 \\
\hline & Kraftliner & air dried t & 11.7 & 401 \\
\hline & Tissue & air dried t & 17.8 & 608 \\
\hline \multicolumn{5}{|l|}{ Pulp and Paper } \\
\hline & Bleached Uncoated Fine & air dried t & 27.1 & 925 \\
\hline & Krafliner (unbleached)/Bag Paper & air dried t & 24.9 & 850 \\
\hline & Bleached Coated Fine & air dried t & 24.9 & 850 \\
\hline & Bleached Uncoated Fine & air dried t & 33.4 & 1139 \\
\hline & Newsprint & air dried t & 31.1 & 1061 \\
\hline & Magazine Paper & air dried t & 22.7 & 775 \\
\hline & Board & air dried t & 22.6 & 772 \\
\hline & Recovered Paper Board & air dried t & 28.6 & 976 \\
\hline & Recovered Paper Newsprint & air dried t & 17.8 & 608 \\
\hline & Recovered Paper Tissue & air dried t & 14.9 & 509 \\
\hline \multicolumn{5}{|l|}{ Ammonia } \\
\hline & Natural Gas Feedstock Steam Reforming & t ammonia & 28 & 956 \\
\hline & Coal Feedstock & t ammonia & 34.8 & 1188 \\
\hline \multicolumn{5}{|l|}{ Ethylene } \\
\hline & Ethane Cracking & $\begin{array}{l}\text { t high value } \\
\text { chemicals }\end{array}$ & 14.5 & 496 \\
\hline & Naphtha Cracking & $\begin{array}{l}\text { t high value } \\
\text { chemicals }\end{array}$ & 13 & 478 \\
\hline
\end{tabular}

Note: Primary energy includes electricity generation, transmission, and distribution losses of $67 \%$. 


\section{World Best Practice Energy Intensity Values}

World best practice energy intensity values for production of iron and steel, aluminium, cement, pulp and paper, ammonia, and ethylene are provided in the following sections.

\subsection{Iron and Steel}

This section provides world best practice energy intensity values by process for iron and steelmaking based on four possible process configurations:

- Blast Furnace - Basic Oxygen Furnace

- Smelt Reduction - Basic Oxygen Furnace

- Direct Reduced Iron - Electric Arc Furnace

- Scrap - Electric Arc Furnace

The world best practice values for these four process configurations are provided separately for hot rolled bars and for cold rolled and finished steel using a continuous caster. In addition, world best practice values are provided for thin slab (near net shape) casting. Tables 2.1.1 and 2.2.2, along with the accompanying text, provide more details on these best practice final and primary energy intensity values, respectively, by process.

Table 2.1.1. World Best Practice Final Energy Intensity Values for Iron and Steel (values are per metric ton of steel).

\begin{tabular}{|c|c|c|c|c|c|c|c|c|c|}
\hline & & \multicolumn{2}{|c|}{$\begin{array}{c}\text { Blast Furnace } \\
\text { - Basic Oxygen } \\
\text { Furnace }\end{array}$} & \multicolumn{2}{|c|}{$\begin{array}{c}\text { Smelt Reduction- } \\
\text { Basic Oxygen } \\
\text { Furnace }\end{array}$} & \multicolumn{2}{|c|}{$\begin{array}{c}\text { Direct Reduced } \\
\text { Iron - Electric } \\
\text { Arc Furnace } \\
\end{array}$} & \multicolumn{2}{|c|}{$\begin{array}{c}\text { Scrap - } \\
\text { Electric Arc } \\
\text { Furnace }\end{array}$} \\
\hline & & $\mathbf{G J} / \mathbf{t}$ & kgce/t & $\mathbf{G J} / \mathbf{t}$ & kgce/t & $\mathbf{G J} / \mathbf{t}$ & kgce/t & $\mathbf{G J} / \mathbf{t}$ & kgce/t \\
\hline \multirow{3}{*}{$\begin{array}{l}\text { Material } \\
\text { Preparation }\end{array}$} & Sintering & 1.9 & 65.2 & & & 1.9 & 65.2 & & \\
\hline & Pelletizing & & & 0.6 & 19.0 & 0.6 & 19.0 & & \\
\hline & Coking & 0.8 & 28.6 & & & & & & \\
\hline \multirow[t]{3}{*}{ Ironmaking } & Blast Furnace & 12.2 & 414.9 & & & & & & \\
\hline & Smelt Reduction & & & 17.3 & 591.6 & & & & \\
\hline & Direct Reduced Iron & & & & & 11.7 & 399.6 & & \\
\hline \multirow[t]{3}{*}{ Steelmaking } & Basic Oxygen Furnace & -0.4 & -15.4 & -0.4 & -15.4 & & & & \\
\hline & Electric Arc Furnace & & & & & 2.5 & 85.6 & 2.4 & 80.6 \\
\hline & Refining & 0.1 & 4.3 & 0.1 & 4.3 & & & & \\
\hline \multirow{2}{*}{$\begin{array}{l}\text { Casting } \\
\text { and Rolling }\end{array}$} & Continuous Casting & 0.1 & 2.0 & 0.1 & 2.0 & 0.1 & 2.0 & 0.1 & 2.0 \\
\hline & Hot Rolling & 1.8 & 62.5 & 1.8 & 62.5 & 1.8 & 62.5 & 1.8 & 62.5 \\
\hline \multicolumn{2}{|l|}{ Sub-Total } & 16.5 & 562.2 & 19.5 & 664.0 & 18.6 & 633.9 & 4.3 & 145.1 \\
\hline \multirow{2}{*}{$\begin{array}{l}\text { Cold Rolling } \\
\text { and Finishing }\end{array}$} & Cold Rolling & 0.4 & 13.7 & 0.4 & 13.7 & & & & \\
\hline & Finishing & 1.1 & 38.1 & 1.1 & 38.1 & & & & \\
\hline Total & & 18.0 & 613.9 & 21.0 & 715.8 & 18.6 & 633.9 & 4.3 & 145.1 \\
\hline Alternative: & Replace Continuous & & & & & & & & \\
\hline $\begin{array}{l}\text { Casting and } \\
\text { Rolling }\end{array}$ & $\begin{array}{l}\text { Casting and Rolling } \\
\text { with Thin Slab Casting }\end{array}$ & 0.2 & 6.9 & 0.2 & 6.9 & 0.2 & 6.9 & 0.2 & 6.9 \\
\hline $\begin{array}{l}\text { Alternative } \\
\text { Total }\end{array}$ & & 14.8 & 504.5 & 17.8 & 606.4 & 16.9 & 576.2 & 2.6 & 87.5 \\
\hline
\end{tabular}

Totals for process routes depend on the feedstock and material flows and differ from plant to plant; totals should not be used to compare individual plants. Hot rolling values are based on energy use for production of hot rolled bars - see following tables for data on hot rolling strip or wire. 
Table 2.1.2. World Best Practice Primary Energy Intensity Values for Iron and Steel (values are per metric ton of steel).

\begin{tabular}{|c|c|c|c|c|c|c|c|c|c|}
\hline & & \multicolumn{2}{|c|}{$\begin{array}{c}\text { Blast Furnace } \\
\text { - Basic Oxygen } \\
\text { Furnace }\end{array}$} & \multicolumn{2}{|c|}{$\begin{array}{c}\text { Smelt Reduction- } \\
\text { Basic Oxygen } \\
\text { Furnace } \\
\end{array}$} & \multicolumn{2}{|c|}{$\begin{array}{c}\text { Direct Reduced } \\
\text { Iron - Electric } \\
\text { Arc Furnace } \\
\end{array}$} & \multicolumn{2}{|c|}{$\begin{array}{c}\text { Scrap - } \\
\text { Electric Arc } \\
\text { Furnace } \\
\end{array}$} \\
\hline & & $\mathbf{G J} / \mathbf{t}$ & kgce/t & $\mathbf{G J} / \mathbf{t}$ & kgce/t & $\mathbf{G J} / \mathbf{t}$ & kgce/t & $\mathbf{G J} / \mathbf{t}$ & kgce/t \\
\hline \multirow{3}{*}{$\begin{array}{l}\text { Material } \\
\text { Preparation }\end{array}$} & Sintering & 2.2 & 74.3 & & & 2.2 & 74.3 & & \\
\hline & Pelletizing & & & 0.8 & 25.7 & 0.8 & 25.7 & & \\
\hline & Coking & 1.1 & 36.3 & & & & & & \\
\hline \multirow[t]{3}{*}{ Ironmaking } & Blast Furnace & 12.4 & 423.7 & & & & & & \\
\hline & Smelt Reduction & & & 17.9 & 610.2 & & & & \\
\hline & Direct Reduced Iron & & & & & 9.2 & 315.6 & & \\
\hline \multirow[t]{3}{*}{ Steelmaking } & Basic Oxygen Furnace & -0.3 & -9.5 & -0.3 & -9.5 & & & & \\
\hline & Electric Arc Furnace & & & & & 5.9 & 202.9 & 5.5 & 187.7 \\
\hline & Refining & 0.4 & 13.0 & 0.4 & 13.0 & & & & \\
\hline \multirow{2}{*}{$\begin{array}{l}\text { Casting } \\
\text { and Rolling }\end{array}$} & Continuous Casting & 0.1 & 3.9 & 0.1 & 3.9 & 0.1 & 3.9 & 0.1 & 3.9 \\
\hline & Hot Rolling & 2.4 & 80.4 & 2.4 & 80.4 & 2.4 & 80.4 & 2.4 & 80.4 \\
\hline \multicolumn{2}{|l|}{ Sub-Total } & 18.2 & 622.0 & 21.2 & 723.7 & 20.6 & 702.7 & 8.0 & 272.0 \\
\hline \multirow{2}{*}{$\begin{array}{l}\text { Cold Rolling } \\
\text { and Finishing }\end{array}$} & Cold Rolling & 0.9 & 32.1 & 0.9 & 32.1 & & & & \\
\hline & Finishing & 1.4 & 48.4 & 1.4 & 48.4 & & & & \\
\hline Total & & 20.6 & 702.5 & 23.6 & 804.2 & 20.6 & 702.7 & 8.0 & 272.0 \\
\hline Alternative: & Replace Continuous & & & & & & & & \\
\hline $\begin{array}{l}\text { Casting and } \\
\text { Rolling }\end{array}$ & $\begin{array}{l}\text { Casting and Rolling } \\
\text { with Thin Slab Casting }\end{array}$ & 0.5 & 17.3 & 0.5 & 17.3 & 0.5 & 17.3 & 0.5 & 17.3 \\
\hline $\begin{array}{l}\text { Alternative } \\
\text { Total }\end{array}$ & & 16.3 & 555.1 & 19.2 & 656.8 & 18.6 & 635.8 & 6.0 & 205.1 \\
\hline
\end{tabular}

Totals for process routes depend on the feedstock and material flows and differ from plant to plant; totals should not be used to compare individual plants. Hot rolling values are based on energy use for production of hot rolled bars - see following tables for data on hot rolling strip or wire.

Note: Primary energy includes electricity generation, transmission, and distribution losses of $67 \%$.

\subsubsection{Blast Furnace - Basic Oxygen Furnace Route}

Table 2.1.3 provides best practice energy consumption values by fuel for the blast furnace - basic oxygen furnace route. These values are based on the International Iron and Steel Institute's (IISI's) EcoTech plant which is defined as "all those proven energy saving technologies that are economically attractive” except for the values for the basic oxygen furnace which are based on IISI's AllTech plant which is defined as "all proven energy saving technologies...regardless of financial viability”. 3

For this steelmaking route, the best practice calculations are based on the following assumptions: $1.389 \mathrm{t}$ sinter are required to produce $1 \mathrm{t}$ hot rolled steel, $90 \%$ pig iron and $10 \%$ scrap, $0.9923 \mathrm{t}$ pig iron required to produce $1 \mathrm{t}$ hot rolled steel, $1.05 \mathrm{t}$ crude steel required to make $1 \mathrm{t}$ hot rolled steel.

\footnotetext{
${ }^{3}$ International Iron and Steel Institute (IISI) 1998. Energy Use in the Steel Industry. Brussels: IISI.
} 
The best practice coke plant is a modern coke plant using standard technology, including electrical exhausters, high-pressure ammonia liquor spray for oven aspiration, as well as variable speed drives on motors and fans. Coke dry quenching saves an additional 1.44 GJ/t (49 kgce/t) coke (beyond the Ecotech value). The best practice does not include a Jumbo Coke Reactor or non-recovery coke ovens. The best practice sinter plant is a stateof-the-art sinter plant using a bed depth of $500 \mathrm{~mm}$ on a moving grate, using coke and breeze as fuel, and gas as ignition furnace fuel. Waste heat is recovered from the sinter exhaust cooler, and air leakage is controlled.

During the ironmaking process, sintered or pelletized iron ore is reduced using coke in combination with injected coal or oil to produce pig iron in a blast furnace. ${ }^{4}$ Limestone is added as a fluxing agent. Reduction of the iron ore is the largest energy-consuming process in the production of primary steel. The best practice blast furnace is a modern large scale blast furnace. Fuel injection rates are similar to modern practices found at various plants around the world (equivalent to about approximately $125 \mathrm{~kg} / \mathrm{t}$ hot metal, slight oxygen enrichment, as well as pressurized operation (4 bar) allowing for power recovery using a top gas power recovery turbine (wet type). Furthermore, the hot blast stoves have a heating efficiency of $85 \%$ using staggered parallel operation with three or four stoves per furnace. Combustion air is preheated. The stoves use a mixture of coke oven and blast furnace gas without oxygen enrichment.

The BOF process operates through the injection of oxygen, oxidizing the carbon in the hot metal. Several configurations exist depending on the way the oxygen is injected. The steel quality can be improved further by ladle refining processes used in the steel mill. The scrap input is rather small for the BOF-route, typically about 10-25\%. The process needs no net input of energy and can even be a net energy exporter in the form of BOFgas and steam. In the best practice case BOF gas and sensible heat are recovered.

\footnotetext{
${ }^{4}$ Best practice energy use is also determined by the concentration and quality of the ore used. As ore is traded internationally (and to China), it is assumed that plants around the world have access to similar qualities of raw materials.
} 
Table 2.1.3. World Best Practice Final and Primary Energy Intensity Values for the Blast Furnace - Basic Oxygen Furnace Steelmaking Route (values are per metric ton of steel)

\begin{tabular}{|c|c|c|c|c|}
\hline \multicolumn{3}{|c|}{ Blast Furnace - Basic Oxygen Furnace Route } & kgce/t & $\mathbf{G J} / \mathbf{t}$ \\
\hline \multirow{10}{*}{ Material Preparation } & \multirow[t]{5}{*}{ Sintering } & Fuel & 67.8 & 2.0 \\
\hline & & Steam & -7.6 & -0.2 \\
\hline & & Electricity & 5.1 & 0.2 \\
\hline & & Final Energy & 65.2 & 1.9 \\
\hline & & Primary Energy & 74.3 & 2.2 \\
\hline & \multirow[t]{5}{*}{ Coking } & Fuel & 21.5 & 0.6 \\
\hline & & Steam & 3.5 & 0.1 \\
\hline & & Electricity & 3.5 & 0.1 \\
\hline & & Final Energy & 28.6 & 0.8 \\
\hline & & Primary Energy & 36.3 & 1.1 \\
\hline \multirow{6}{*}{ Ironmaking } & \multirow[t]{6}{*}{ Blast Furnace } & Fuel & 390.5 & 11.4 \\
\hline & & Steam & 13.6 & 0.4 \\
\hline & & Electricity & 3.1 & 0.1 \\
\hline & & Oxygen & 7.7 & 0.2 \\
\hline & & Final Energy & 414.9 & 12.2 \\
\hline & & Primary Energy & 423.7 & 12.4 \\
\hline \multirow{9}{*}{ Steelmaking } & \multirow[t]{6}{*}{ Basic Oxygen Furnace } & Fuel & -25.4 & -0.7 \\
\hline & & Steam & -5.4 & -0.2 \\
\hline & & Electricity & 3.4 & 0.1 \\
\hline & & Oxygen & 12.1 & 0.4 \\
\hline & & Final Energy & -15.4 & -0.4 \\
\hline & & Primary Energy & -9.5 & -0.3 \\
\hline & \multirow[t]{3}{*}{ Refining } & Electricity & 4.3 & 0.1 \\
\hline & & Final Energy & 4.3 & 0.1 \\
\hline & & Primary Energy & 13.0 & 0.4 \\
\hline \multirow{4}{*}{ Casting } & \multirow[t]{4}{*}{ Continuous Casting } & Fuel & 1.0 & 0.0 \\
\hline & & Electricity & 0.9 & 0.0 \\
\hline & & Final Energy & 2.0 & 0.1 \\
\hline & & Primary Energy & 3.9 & 0.1 \\
\hline \multirow{13}{*}{ Hot Rolling } & \multirow[t]{5}{*}{ Hot Rolling - Strip } & Fuel & 44.8 & 1.3 \\
\hline & & Steam & 0.7 & 0.0 \\
\hline & & Electricity & 10.2 & 0.3 \\
\hline & & Final Energy & 55.7 & 1.6 \\
\hline & & Primary Energy & 76.5 & 2.2 \\
\hline & \multirow[t]{4}{*}{ Hot Rolling - Bars } & Fuel & 53.8 & 1.6 \\
\hline & & Electricity & 8.8 & 0.3 \\
\hline & & Final Energy & 62.5 & 1.8 \\
\hline & & Primary Energy & 80.4 & 2.4 \\
\hline & \multirow[t]{4}{*}{ Hot Rolling - Wire } & Fuel & 57.3 & 1.7 \\
\hline & & Electricity & 13.5 & 0.4 \\
\hline & & Final Energy & 70.9 & 2.1 \\
\hline & & Primary Energy & 98.4 & 2.9 \\
\hline \multirow{6}{*}{$\begin{array}{l}\text { Sub Total } \\
\text { (based on hot rolling-bars) }\end{array}$} & & Fuel & 509.1 & 14.9 \\
\hline & & Steam & 4.2 & 0.1 \\
\hline & & Electricity & 29.1 & 0.9 \\
\hline & & Oxygen & 19.8 & 0.6 \\
\hline & & Final Energy & 562.2 & 16.5 \\
\hline & & Primary Energy & 622.0 & 18.2 \\
\hline
\end{tabular}

Note: Primary energy includes electricity generation, transmission, and distribution losses of $67 \%$. 
Table 2.1.3. (continued) World Best Practice Final and Primary Energy Intensity Values for the Blast Furnace - Basic Oxygen Furnace Steelmaking Route (values are per metric ton of steel)

\begin{tabular}{|c|c|c|c|c|}
\hline \multicolumn{3}{|c|}{ Blast Furnace - Basic Oxygen Furnace Route } & \multirow{2}{*}{$\frac{\text { kgce/t }}{1.8}$} & \multirow{2}{*}{$\frac{\mathbf{G J} / \mathbf{t}}{0.1}$} \\
\hline Cold Rolling & Cold Rolling & Fuel & & \\
\hline & & Steam & 3.0 & 0.1 \\
\hline & & Electricity & 8.8 & 0.3 \\
\hline & & Final Energy & 13.7 & 0.4 \\
\hline & & Primary Energy & 32.1 & 0.9 \\
\hline \multirow[t]{5}{*}{ Finishing } & \multirow[t]{5}{*}{ Finishing } & Fuel & 24.9 & 0.7 \\
\hline & & Steam & 8.9 & 0.3 \\
\hline & & Electricity & 4.3 & 0.1 \\
\hline & & Final Energy & 38.1 & 1.1 \\
\hline & & Primary Energy & 48.4 & 1.4 \\
\hline \multirow{6}{*}{$\begin{array}{l}\text { Total } \\
\text { (based on hot rolling-bars) }\end{array}$} & & Fuel & 535.8 & 15.7 \\
\hline & & Steam & 16.0 & 0.5 \\
\hline & & Electricity & 42.3 & 1.2 \\
\hline & & Oxygen & 19.8 & 0.6 \\
\hline & & Final Energy & 613.9 & 18.0 \\
\hline & & Primary Energy & 702.5 & 20.6 \\
\hline \multicolumn{5}{|l|}{ Alternative: } \\
\hline \multirow[t]{4}{*}{ Casting and Rolling } & \multirow{4}{*}{$\begin{array}{l}\text { Replace Continuous } \\
\text { Casting, Hot Rolling, Cold } \\
\text { Rolling, and Finishing with } \\
\text { Thin Slab Casting }\end{array}$} & Fuel & 1.7 & 0.1 \\
\hline & & Electricity & 5.2 & 0.2 \\
\hline & & Final Energy & 6.9 & 0.2 \\
\hline & & Primary Energy & 17.3 & 0.5 \\
\hline \multirow[t]{6}{*}{ Total } & & Fuel & 456.0 & 13.4 \\
\hline & & Steam & 4.2 & 0.1 \\
\hline & & Electricity & 24.5 & 0.7 \\
\hline & & Oxygen & 19.8 & 0.6 \\
\hline & & Final Energy & 504.5 & 14.8 \\
\hline & & Primary Energy & 555.1 & 16.3 \\
\hline
\end{tabular}

Note: Primary energy includes electricity generation, transmission, and distribution losses of $67 \%$. 


\subsubsection{Smelt Reduction - Basic Oxygen Furnace}

Table 2.1.4 provides best practice energy consumption values by fuel for the smelt reduction - basic oxygen furnace (BOF) route. These values are based on the International Iron and Steel Institute's (IISI's) EcoTech plant which is defined as "all those proven energy saving technologies that are economically attractive". 5

Smelt reduction processes are the latest development in pig iron production and omit coke production by combining the gasification of coal with the melt reduction of iron ore. ${ }^{6}$ Energy consumption is reduced because production of coke is abolished and iron ore preparation is reduced. Processes under development include CCF, DIOS, AISI, and HISmelt. Currently, only the COREX process (Voest-Alpine, Austria) is commercial and operating in South Africa, South Korea and India, and under construction at Baosteel in China (startup in 2007). The COREX process uses agglomerated ore, which is prereduced by gases coming from a hot bath. The pre-reduced iron is then melted in the bath. The process produces excess gas, which is used for power generation, DRI-production, or as fuel gas. The FINEX technology allows the use of ore fines, but the first commercial plant is now under construction and hence not included in the best practice. Likewise the first commercial plant using the HISmelt process is under construction in Australia.

Currently operating COREX plants show net energy consumption levels comparable to the blast furnace routes. The coal consumption rate is higher than that of current blast furnaces, but a large volume of offgas is produced that is used as fuel for power generation using a conventional steam cycle. The offgas can also be used to produce DRI (as in practice at Saldanha steel in South Africa), but this is not assumed as part of this best practice.

The best practice values for the COREX plant are based on the commercially operating plant at POSCO's Pohang site in Korea. ${ }^{7}$ The plant coal consumption is around 29.4 GJ/thm (100 kgce/t), 75 kWh/t (9.2 kgce/t) hot metal electricity and 526 Nm3/t hot metal of oxygen. It exports offgases with an energy value of $13.4 \mathrm{GJ} / \mathrm{t}(457 \mathrm{kgce} / \mathrm{t})$ hot metal. ${ }^{8}$

The BOF process operates through the injection of oxygen, oxidizing the carbon in the hot metal. Several configurations exist depending on the way the oxygen is injected. The steel quality can be improved further by ladle refining processes used in the steel mill. The scrap input is rather small for the BOF-route, typically about $10-25 \%$. The process needs no net input of energy and can even be a net energy exporter in the form of BOFgas and steam.

\footnotetext{
${ }^{5}$ International Iron and Steel Institute (IISI) 1998. Energy Use in the Steel Industry. Brussels: IISI.

${ }^{6}$ Best practice energy use is also determined by the concentration and quality of the ore used; it is assumed that all plants have access to similar qualities of raw materials.

${ }^{7}$ Voest Alpine Industrieanlagenbau, 1996. COREX, Revolution in Ironmaking, Linz, Austria:VAI.;de Beer, J., Worrell, E., Blok, K., 1998. "Future Technologies for Energy-Efficient Iron and Steel Making,” Annual Review of Energy and Environment, 23: 123-205.

${ }^{8}$ International Iron and Steel Institute (IISI) 1998. Energy Use in the Steel Industry. Brussels: IISI.
} 
Table 2.1.4. World Best Practice Final and Primary Energy Intensity Values for the Smelt Reduction - Basic Oxygen Furnace Steelmaking Route (values are per metric ton of steel)

\begin{tabular}{|c|c|c|c|c|}
\hline \multicolumn{3}{|c|}{ Smelt Reduction- Basic Oxygen Furnace } & \multirow{2}{*}{$\frac{\text { kgce/t }}{15.6}$} & \multirow{2}{*}{$\frac{\mathbf{G J} / \mathbf{t}}{0.5}$} \\
\hline \multirow{4}{*}{$\begin{array}{l}\text { Material } \\
\text { Preparation }\end{array}$} & \multirow[t]{4}{*}{ Pelletizing } & Fuel & & \\
\hline & & Electricity & 3.3 & 0.1 \\
\hline & & Final Energy & 19.0 & 0.6 \\
\hline & & Primary Energy & 25.7 & 0.8 \\
\hline \multirow{5}{*}{ Ironmaking } & \multirow[t]{5}{*}{ Smelt Reduction } & Fuel & 541.8 & 15.9 \\
\hline & & Electricity & 9.1 & 0.3 \\
\hline & & Oxygen & 40.6 & 1.2 \\
\hline & & Final Energy & 591.6 & 17.3 \\
\hline & & Primary Energy & 610.2 & 17.9 \\
\hline \multirow{9}{*}{ Steelmaking } & \multirow[t]{6}{*}{ Basic Oxygen Furnace } & Fuel & -25.4 & -0.7 \\
\hline & & Steam & -5.4 & -0.2 \\
\hline & & Electricity & 3.4 & 0.1 \\
\hline & & Oxygen & 12.1 & 0.4 \\
\hline & & Final Energy & -15.4 & -0.4 \\
\hline & & Primary Energy & -9.5 & -0.3 \\
\hline & \multirow[t]{3}{*}{ Refining } & Electricity & 4.3 & 0.1 \\
\hline & & Final Energy & 4.3 & 0.1 \\
\hline & & Primary Energy & 13.0 & 0.4 \\
\hline \multirow[t]{4}{*}{ Casting } & \multirow[t]{4}{*}{ Continuous Casting } & Fuel & 1.0 & 0.0 \\
\hline & & Electricity & 0.9 & 0.0 \\
\hline & & Final Energy & 2.0 & 0.1 \\
\hline & & Primary Energy & 3.9 & 0.1 \\
\hline \multirow{13}{*}{ Hot Rolling } & \multirow[t]{5}{*}{ Hot Rolling - Strip } & Fuel & 44.8 & 1.3 \\
\hline & & Steam & 0.7 & 0.0 \\
\hline & & Electricity & 10.2 & 0.3 \\
\hline & & Final Energy & 55.7 & 1.6 \\
\hline & & Primary Energy & 76.5 & 2.2 \\
\hline & \multirow[t]{4}{*}{ Hot Rolling - Bars } & Fuel & 53.8 & 1.6 \\
\hline & & Electricity & 8.8 & 0.3 \\
\hline & & Final Energy & 62.5 & 1.8 \\
\hline & & Primary Energy & 80.4 & 2.4 \\
\hline & \multirow[t]{4}{*}{ Hot Rolling - Wire } & Fuel & 57.3 & 1.7 \\
\hline & & Electricity & 13.5 & 0.4 \\
\hline & & Final Energy & 70.9 & 2.1 \\
\hline & & Primary Energy & 98.4 & 2.9 \\
\hline \multirow{6}{*}{$\begin{array}{l}\text { Sub Total } \\
\text { (based on hot rolling-bars) }\end{array}$} & & Fuel & 586.8 & 17.2 \\
\hline & & Steam & -5.4 & -0.2 \\
\hline & & Electricity & 29.8 & 0.9 \\
\hline & & Oxygen & 52.8 & 1.5 \\
\hline & & Final Energy & 664.0 & 19.5 \\
\hline & & Primary Energy & 723.7 & 21.2 \\
\hline
\end{tabular}

Note: Primary energy includes electricity generation, transmission, and distribution losses of $67 \%$. 
Table 2.1.4. (continued) World Best Practice Final and Primary Energy Intensity Values for the Smelt Reduction - Basic Oxygen Furnace Steelmaking Route (values are per metric ton of steel)

\begin{tabular}{|c|c|c|c|c|}
\hline \multicolumn{3}{|c|}{ Smelt Reduction- Basic Oxygen Furnace } & \multirow{2}{*}{$\frac{\text { kgce/t }}{1.8}$} & \multirow{2}{*}{$\frac{\mathbf{G J} / \mathbf{t}}{0.1}$} \\
\hline Cold Rolling & Cold Rolling & Fuel & & \\
\hline & & Steam & 3.0 & 0.1 \\
\hline & & Electricity & 8.8 & 0.3 \\
\hline & & Final Energy & 13.7 & 0.4 \\
\hline & & Primary Energy & 32.1 & 0.9 \\
\hline \multirow[t]{5}{*}{ Finishing } & \multirow[t]{5}{*}{ Finishing } & Fuel & 24.9 & 0.7 \\
\hline & & Steam & 8.9 & 0.3 \\
\hline & & Electricity & 4.3 & 0.1 \\
\hline & & Final Energy & 38.1 & 1.1 \\
\hline & & Primary Energy & 48.4 & 1.4 \\
\hline \multirow{6}{*}{$\begin{array}{l}\text { Total } \\
\text { (based on hot rolling-bars) }\end{array}$} & & Fuel & 613.5 & 18.0 \\
\hline & & Steam & 6.5 & 0.2 \\
\hline & & Electricity & 43.0 & 1.3 \\
\hline & & Oxygen & 52.8 & 1.5 \\
\hline & & Final Energy & 715.8 & 21.0 \\
\hline & & Primary Energy & 804.2 & 23.6 \\
\hline \multicolumn{5}{|l|}{ Alternative: } \\
\hline \multirow[t]{4}{*}{ Casting and Rolling } & \multirow{4}{*}{$\begin{array}{l}\text { Replace Continuous } \\
\text { Casting, Hot Rolling, Cold } \\
\text { Rolling, and Finishing with } \\
\text { Thin Slab Casting }\end{array}$} & Fuel & 1.7 & 0.1 \\
\hline & & Electricity & 5.2 & 0.2 \\
\hline & & Final Energy & 6.9 & 0.2 \\
\hline & & Primary Energy & 17.3 & 0.5 \\
\hline \multirow[t]{6}{*}{ Total } & & Fuel & 533.8 & 15.6 \\
\hline & & Steam & -5.4 & -0.2 \\
\hline & & Electricity & 25.3 & 0.7 \\
\hline & & Oxygen & 52.8 & 1.5 \\
\hline & & Final Energy & 606.4 & 17.8 \\
\hline & & Primary Energy & 656.8 & 19.2 \\
\hline
\end{tabular}

Note: Primary energy includes electricity generation, transmission, and distribution losses of $67 \%$. 


\subsubsection{Direct Reduced Iron - Electric Arc Furnace}

Table 2.1.5 provides best practice energy consumption values by fuel for the direct reduced iron - electric arc furnace (DRI - EAF) route. DRI, hot briquetted iron (HBI), and iron carbide are all alternative iron making processes. ${ }^{9}$ DRI, also called sponge iron, is produced by reduction of the ores below the melting point in small-scale plants $(<1$ Mt/year) and has different properties than pig iron. DRI serves as a high-quality alternative for scrap in secondary steelmaking.

DRI plants use either natural gas or coal as reductant. Globally, natural gas is widely preferred, and used in the leading processes Midrex and HyL-III. For China a coal-based process is more appropriate as natural gas availability is still limited to a small number of regions. The SL/RN process is the only commercial coal-based DRI process and in use in India and South Africa, as well as China. However, the new Circofer/Circored process has now been demonstrated in Trinidad, while other technologies are actively being tested. For best practice the SL/RN process is used. The SL/RN process consumes 19.5 GJ/t DRI (665 kgce/t DRI) of coal and $100 \mathrm{kWh}$ of electricity. The waste heat from the furnace is used to generate power in a conventional steam cycle, equivalent to $609 \mathrm{kWh} / \mathrm{t}$ DRI. Net power production is estimated at $509 \mathrm{kWh} / \mathrm{t}$ DRI (62.5 kgce/t DRI). ${ }^{10}$

In the EAF steelmaking process, the coke production, pig iron production, and steel production steps are omitted, resulting in much lower energy consumption. To produce EAF steel, scrap is melted and refined, using a strong electric current. The EAF can also be fed with iron from the DRI route, but electricity consumption will increase by 40-120 $\mathrm{kWh} / \mathrm{t}$ liquid steel depending on the amount of DRI and degree of metallization of the DRI. DRI is used to enhance steel quality or if high quality scrap is scarce or expensive. Several process variations exist using either AC or DC currents, and fuels can be injected to reduce electricity use.

The best practice EAF plant is state-of-the-art facility with eccentric bottom tapping, ultra high power transformers, oxygen blowing, and carbon injection. The furnace uses a mix of $60 \%$ DRI and $40 \%$ high quality scrap. The high DRI charge rate limits the feasibility of fuel injection. The best practice excludes scrap preheating, although this is used in large scale furnaces. For the above charge the scrap preheater would achieve electricity savings of $40 \mathrm{kWh} / \mathrm{t}$ liquid steel.

The best practice DRI-scrap-fed EAF consumes a mix of $60 \%$ DRI and $40 \%$ scrap. It consumes $530 \mathrm{kWh} / \mathrm{t}(65 \mathrm{kgce} / \mathrm{t})$ liquid steel for the EAF and $65 \mathrm{kWh} / \mathrm{t}(8 \mathrm{kgce} / \mathrm{t})$ liquid steel for gas cleaning and ladle refining, as well as $8 \mathrm{~kg} / \mathrm{t}$ liquid steel of carbon. Installing a scrap preheater will reduce power use in the EAF by $40 \mathrm{kWh} / \mathrm{t}$ ( $4.9 \mathrm{kgce} / \mathrm{t})$ liquid steel, reducing total electricity use to $555 \mathrm{kWh} / \mathrm{t}$ (68.2 kgce/t) liquid steel.

\footnotetext{
${ }^{9}$ McAloon, T.P., 1994. “Alternate Ironmaking Update,” Iron \& Steelmaker 21(2): 37-39 + 55.

${ }^{10}$ International Iron and Steel Institute (IISI) 1998. Energy Use in the Steel Industry. Brussels: IISI.
} 
Table 2.1.5. World Best Practice Final and Primary Energy Intensity Values for Direct Reduced Iron - Electric Arc Furnace Route (values are per metric ton of steel)

\begin{tabular}{|c|c|c|c|c|}
\hline \multicolumn{3}{|c|}{ Direct Reduced Iron - Electric Arc Furnace Route } & \multirow{2}{*}{$\frac{\mathbf{k g c e} / \mathbf{t}}{67.8}$} & \multirow{2}{*}{$\frac{\mathbf{G J} / \mathbf{t}}{2.0}$} \\
\hline \multirow{9}{*}{$\begin{array}{l}\text { Material } \\
\text { Preparation }\end{array}$} & \multirow[t]{5}{*}{ Sintering } & Fuel & & \\
\hline & & Steam & -7.6 & -0.2 \\
\hline & & Electricity & 5.1 & 0.2 \\
\hline & & Final Energy & 65.2 & 1.9 \\
\hline & & Primary Energy & 74.3 & 2.2 \\
\hline & \multirow[t]{4}{*}{ Pelletizing } & Fuel & 15.6 & 0.5 \\
\hline & & Electricity & 3.3 & 0.1 \\
\hline & & Final Energy & 19.0 & 0.6 \\
\hline & & Primary Energy & 25.7 & 0.8 \\
\hline \multirow{4}{*}{ Ironmaking } & \multirow[t]{4}{*}{ Direct Reduced Iron } & Fuel & 440.9 & 12.9 \\
\hline & & Electricity & -41.4 & -1.2 \\
\hline & & Final Energy & 399.6 & 11.7 \\
\hline & & Primary Energy & 315.6 & 9.2 \\
\hline \multirow{5}{*}{ Steelmaking } & \multirow[t]{5}{*}{ Electric Arc Furnace } & Fuel & 19.2 & 0.6 \\
\hline & & Electricity & 57.8 & 1.7 \\
\hline & & Oxygen & 8.6 & 0.3 \\
\hline & & Final Energy & 85.6 & 2.5 \\
\hline & & Primary Energy & 202.9 & 5.9 \\
\hline \multirow[t]{4}{*}{ Casting } & \multirow[t]{4}{*}{ Continuous Casting } & Fuel & 1.0 & 0.03 \\
\hline & & Electricity & 0.9 & 0.03 \\
\hline & & Final Energy & 2.0 & 0.1 \\
\hline & & Primary Energy & 3.9 & 0.1 \\
\hline \multirow{13}{*}{ Hot Rolling } & \multirow[t]{5}{*}{ Hot Rolling - Strip } & Fuel & 44.8 & 1.3 \\
\hline & & Steam & 0.7 & 0.02 \\
\hline & & Electricity & 10.2 & 0.3 \\
\hline & & Final Energy & 55.7 & 1.6 \\
\hline & & Primary Energy & 76.5 & 2.2 \\
\hline & \multirow[t]{4}{*}{ Hot Rolling - Bars } & Fuel & 53.8 & 1.6 \\
\hline & & Electricity & 8.8 & 0.3 \\
\hline & & Final Energy & 62.5 & 1.8 \\
\hline & & Primary Energy & 80.4 & 2.4 \\
\hline & \multirow[t]{4}{*}{ Hot Rolling - Wire } & Fuel & 57.3 & 1.7 \\
\hline & & Electricity & 13.5 & 0.4 \\
\hline & & Final Energy & 70.9 & 2.1 \\
\hline & & Primary Energy & 98.4 & 2.9 \\
\hline \multirow{6}{*}{$\begin{array}{l}\text { Total } \\
\text { (based on hot rolling-bars) }\end{array}$} & & Fuel & 598.3 & 17.5 \\
\hline & & Steam & -7.6 & -0.2 \\
\hline & & Electricity & 34.6 & 1.0 \\
\hline & & Oxygen & 8.6 & 0.3 \\
\hline & & Final Energy & 633.9 & 18.6 \\
\hline & & Primary Energy & 702.7 & 20.6 \\
\hline
\end{tabular}

Note: Primary energy includes electricity generation, transmission, and distribution losses of 67\%. 
Table 2.1.5. (continued) World Best Practice Final and Primary Energy Intensity Values for Direct Reduced Iron - Electric Arc Furnace Route (values are per metric ton of steel)

\begin{tabular}{|c|c|c|c|c|}
\hline \multicolumn{3}{|c|}{ Direct Reduced Iron - Electric Arc Furnace Route } & kgce/t & $\mathbf{G J} / \mathbf{t}$ \\
\hline \multicolumn{5}{|l|}{ Alternative: } \\
\hline \multirow[t]{4}{*}{ Casting and Rolling } & \multirow{4}{*}{$\begin{array}{l}\text { Replace Continuous } \\
\text { Casting, Hot Rolling, Cold } \\
\text { Rolling, and Finishing with } \\
\text { Thin Slab Casting }\end{array}$} & Fuel & 1.7 & 0.1 \\
\hline & & Electricity & 5.2 & 0.2 \\
\hline & & Final Energy & 6.9 & 0.2 \\
\hline & & Primary Energy & 17.3 & 0.5 \\
\hline \multirow[t]{6}{*}{ Total } & & Fuel & 545.2 & 16.0 \\
\hline & & Steam & -7.6 & -0.2 \\
\hline & & Electricity & 30.0 & 0.9 \\
\hline & & Oxygen & 8.6 & 0.3 \\
\hline & & Final Energy & 576.2 & 16.9 \\
\hline & & Primary Energy & 635.8 & 18.6 \\
\hline
\end{tabular}

Note: Primary energy includes electricity generation, transmission, and distribution losses of $67 \%$.

\subsubsection{Electric Arc Furnace}

In the EAF steelmaking process, the coke production, pig iron production, and steel production steps are omitted, resulting in much lower energy consumption. To produce EAF steel, scrap is melted and refined, using a strong electric current. Several process variations exist, using either AC or DC currents and fuels can be injected to reduce electricity use.

Table 2.1.6 provides best practice energy consumption values by fuel for the EAF route. The best practice EAF plant is state-of-the-art facility using $100 \%$ high quality scrap. The EAF is equipped with eccentric bottom tapping, ultra high power transformers, oxygen blowing, full foamy slag operation, oxy-fuel burners, and carbon injection. Scrap preheating is not assumed, although economically attractive, especially for large scale furnaces. Scrap preheating will reduce power consumption by $70 \mathrm{kWh} / \mathrm{t}(8.6 \mathrm{kgce} / \mathrm{t})$ liquid steel.

The "best practice" DRI-scrap-fed EAF consumes 100\% scrap. It consumes $409 \mathrm{kWh} / \mathrm{t}$ (50.3 kgce/t) liquid steel for the EAF and $65 \mathrm{kWh} / \mathrm{t}$ (8 kgce/t) liquid steel for gas cleaning and ladle refining, as well as $0.15 \mathrm{GJ} / \mathrm{t}$ (5.1 kgce/t) liquid steel of natural gas and $8 \mathrm{~kg} / \mathrm{t}$ liquid steel of carbon. Installing a scrap preheater would reduce power use in the EAF by $70 \mathrm{kWh} / \mathrm{t}$ (8.6 kgce/t), reducing total electricity use to $404 \mathrm{kWh} / \mathrm{t}$ (49.6 kgce/t) liquid steel. 
Table 2.1.6. World Best Practice Final and Primary Energy Intensity Values for Electric Arc Furnace Route (values are per metric ton of steel)

\begin{tabular}{|c|c|c|c|c|}
\hline \multicolumn{3}{|c|}{ Electric Arc Furnace Route } & \multirow{2}{*}{$\frac{\text { kgce/t }}{19.2}$} & \multirow{2}{*}{$\frac{\mathbf{G J} / \mathbf{t}}{0.6}$} \\
\hline \multirow{5}{*}{ Steelmaking } & \multirow[t]{5}{*}{ Electric Arc Furnace } & Fuel & & \\
\hline & & Electricity & 52.8 & 1.5 \\
\hline & & Oxygen & 8.6 & 0.3 \\
\hline & & Final Energy & 80.6 & 2.4 \\
\hline & & Primary Energy & 187.7 & 5.5 \\
\hline \multirow[t]{4}{*}{ Casting } & \multirow[t]{4}{*}{ Continuous Casting } & Fuel & 1.0 & 0.03 \\
\hline & & Electricity & 0.9 & 0.03 \\
\hline & & Final Energy & 2.0 & 0.1 \\
\hline & & Primary Energy & 3.9 & 0.1 \\
\hline \multirow{13}{*}{ Hot Rolling } & \multirow[t]{5}{*}{ Hot Rolling - Strip } & Fuel & 44.8 & 1.3 \\
\hline & & Steam & 0.7 & 0.02 \\
\hline & & Electricity & 10.2 & 0.3 \\
\hline & & Final Energy & 55.7 & 1.6 \\
\hline & & Primary Energy & 76.5 & 2.2 \\
\hline & \multirow[t]{4}{*}{ Hot Rolling - Bars } & Fuel & 53.8 & 1.6 \\
\hline & & Electricity & 8.8 & 0.3 \\
\hline & & Final Energy & 62.5 & 1.8 \\
\hline & & Primary Energy & 80.4 & 2.4 \\
\hline & \multirow[t]{4}{*}{ Hot Rolling - Wire } & Fuel & 57.3 & 1.7 \\
\hline & & Electricity & 13.5 & 0.4 \\
\hline & & Final Energy & 70.9 & 2.1 \\
\hline & & Primary Energy & 98.4 & 2.9 \\
\hline \multirow{5}{*}{$\begin{array}{l}\text { Total } \\
\text { (based on hot rolling-bars) }\end{array}$} & & Fuel & 74.0 & 2.2 \\
\hline & & Electricity & 62.5 & 1.8 \\
\hline & & Oxygen & 8.6 & 0.3 \\
\hline & & Final Energy & 145.1 & 4.3 \\
\hline & & Primary Energy & 272.0 & 8.0 \\
\hline \multicolumn{5}{|l|}{ Alternative: } \\
\hline \multirow[t]{4}{*}{ Casting and Rolling } & \multirow{4}{*}{$\begin{array}{l}\text { Replace Continuous } \\
\text { Casting, Hot Rolling, Cold } \\
\text { Rolling, and Finishing with } \\
\text { Thin Slab Casting }\end{array}$} & Fuel & 1.7 & 0.1 \\
\hline & & Electricity & 5.2 & 0.2 \\
\hline & & Final Energy & 6.9 & 0.2 \\
\hline & & Primary Energy & 17.3 & 0.5 \\
\hline \multirow[t]{5}{*}{ Total } & & Fuel & 20.9 & 0.6 \\
\hline & & Electricity & 57.9 & 1.7 \\
\hline & & Oxygen & 8.6 & 0.3 \\
\hline & & Final Energy & 87.5 & 2.6 \\
\hline & & Primary Energy & 205.1 & 6.0 \\
\hline
\end{tabular}

Note: Primary energy includes electricity generation, transmission, and distribution losses of $67 \%$.

\subsubsection{Casting}

Continuous casting values are based on the International Iron and Steel Institute's EcoTech plant which includes "all those proven energy saving technologies that are economically attractive" 11 and the thin slab/near net shape casting values are based on Worrell et al. (2004). ${ }^{12}$ Casting can be either continuous casting or thin slab/near net

\footnotetext{
11 International Iron and Steel Institute (IISI) 1998. Energy Use in the Steel Industry. Brussels: IISI.

12 Worrell, E., Price, L., and Galitsky, C., 2004. "Emerging Energy-Efficient Technologies in Industry: Case Study of Selected Technologies," Technical Appendix Chapter 3: Improving Energy Efficiency of
} 
shape casting. Best practice continuous casting uses $0.06 \mathrm{GJ} / \mathrm{t}(2.0 \mathrm{kgce} / \mathrm{t})$ steel of final energy. ${ }^{13}$ Energy is only used to dry and preheat the ladles, heat the tundish, and for motors to drive the casting equipment. Thin slab/near net shape casting is a more advanced casting technique which reduces the need for hot rolling because products are initially cast closer to their final shape using a simplified rolling strand positioned behind the caster's reheating tunnel furnace, eliminating the need for a separate hot rolling mill. Final energy used for casting and rolling using thin slab casting is $0.20 \mathrm{GJ} / \mathrm{t}$ (6.9 kgce/t) steel.

\subsubsection{Rolling and Finishing}

\section{Hot Rolling}

Rolling of the cast steel begins in the hot rolling mill where the steel is heated and passed through heavy roller sections to reduce the thickness. Best practice values for hot rolling are $1.55 \mathrm{GJ} / \mathrm{t}$ (53.0 kgce/t), $1.75 \mathrm{GJ} / \mathrm{t}$ (59.6 kgce/t), and $1.98 \mathrm{GJ} / \mathrm{t}(67.5 \mathrm{kgce} / \mathrm{t})$ of steel of final energy for rolling strip, bars, and wire, respectively. ${ }^{14}$ Electricity consumption for the best practice hot strip mill is based on hot strip mill 2 at Corus, IJmuiden, Netherlands. ${ }^{15}$ The best practice values assume $100 \%$ cold charging, a walking beam furnace with furnace controls and energy efficient burners, and efficient motors. Hot charging and premium efficiency motors may further reduce the rolling mill energy use.

\section{Cold Rolling}

The hot rolled sheets may be further reduced in thickness by cold rolling. The coils are first treated in a pickling line followed by treatment in a tandem mill. The best practice final energy intensity for cold rolling is $0.09 \mathrm{GJ} / \mathrm{t}(3.0 \mathrm{kgce} / \mathrm{t})$ steam, fuel use of 0.053 $\mathrm{GJ} / \mathrm{t}$ (1.8 kgce/t) and electricity use of $87 \mathrm{kWh} / \mathrm{t}(10.7 \mathrm{kgce} / \mathrm{t})$ cold rolled sheet, ${ }^{16}$ equivalent to $0.47 \mathrm{GJ} / \mathrm{t}(13.7 \mathrm{kgce} / \mathrm{t})$ cold sheet.

\section{Finishing}

Finishing is the final production step, and may include different processes such as annealing and surface treatment. The best practice final energy intensity for batch annealing is steam use of $0.173 \mathrm{GJ} / \mathrm{t}$, fuel use of $0.9 \mathrm{GJ} / \mathrm{t}$ and $35 \mathrm{kWh} / \mathrm{t}$ of electricity, equivalent to $1.2 \mathrm{GJ} / \mathrm{t}$ (41.0 kgce/t). Best practice energy use for continuous annealing is assumed to be equal to fuel use of $0.73 \mathrm{GJ} / \mathrm{t}$, steam use of $0.26 \mathrm{GJ} / \mathrm{t}$, and electricity use of $35 \mathrm{kWh} / \mathrm{t}$, equivalent to final energy use of $1.1 \mathrm{GJ} / \mathrm{t}$ (or $38.1 \mathrm{kgce} / \mathrm{t}$ ). Continuous annealing is considered the state-of-the-art technology, and therefore assumed to be best practice technology.

National Commission on Energy Policy report Ending the Energy Stalemate: A Bipartisan Strategy to Meet America's Energy Challenges (http://www.energycommission.org/)

${ }^{13}$ International Iron and Steel Institute (IISI) 1998. Energy Use in the Steel Industry. Brussels: IISI.

${ }^{14}$ International Iron and Steel Institute (IISI) 1998. Energy Use in the Steel Industry. Brussels: IISI.

${ }^{15}$ Worrell, E. 1994. Potentials for Improved Use of Industrial Energy and Materials, Ph.D. Thesis, Utrecht University, June 1994.

${ }^{16}$ International Iron and Steel Institute (IISI) 1998. Energy Use in the Steel Industry. Brussels: IISI. 


\subsection{Aluminium}

There are five steps in the primary aluminium production process: bauxite extraction, alumina production, anode manufacture, aluminium smelting, and ingot casting. This assessment excludes bauxite extraction because the energy use will primarily depend on the ore deposit characteristics. Secondary aluminium production is based on melting and reshaping scrap aluminium. Table 2.2.1 provides best practice final energy intensity values for the process steps for primary aluminium production along with the best practice energy intensity value for secondary aluminium production. Table 2.2.2 provides primary energy values for these two aluminium production processes.

Table 2.2.1. World Best Practice Final Energy Intensity Values for Aluminium Production (values are per metric tonne aluminium).

\begin{tabular}{|l|l|c|c|c|c|}
\hline \multirow{2}{*}{} & & \multicolumn{2}{c|}{$\begin{array}{c}\text { Primary } \\
\text { Aluminium }\end{array}$} & \multicolumn{2}{c|}{$\begin{array}{c}\text { Secondary } \\
\text { Aluminium }\end{array}$} \\
\hline \multirow{2}{*}{$\begin{array}{l}\text { Alumina Production } \\
\text { (Bayer) }\end{array}$} & & kgce/t & GJ/t & kgce/t & GJ/t \\
\hline & Digesting (fuel) & 414 & 12.1 & & \\
\cline { 2 - 6 } & Calcining Kiln (fuel) & 223 & 6.5 & & \\
\cline { 2 - 6 } $\begin{array}{l}\text { Anode Manufacture } \\
\text { (Carbon) }\end{array}$ & Electricity & 48 & 1.4 & & \\
\hline Aluminium Smelting (Electrolysis) & Fuel & 35 & 1.0 & & \\
\hline & Electricity & 7 & 0.21 & & \\
\hline Ingot Casting & Electricity & 1671 & 49.0 & & \\
\hline Total & Electricity & 12 & 0.35 & & \\
\hline
\end{tabular}

Table 2.2.2. World Best Practice Primary Energy Intensity Values for Aluminium Production (values are per metric tonne aluminium).

\begin{tabular}{|l|l|c|c|c|c|}
\hline \multirow{2}{*}{} & & \multicolumn{2}{c|}{$\begin{array}{c}\text { Primary } \\
\text { Aluminium }\end{array}$} & \multicolumn{2}{c|}{$\begin{array}{c}\text { Secondary } \\
\text { Aluminium }\end{array}$} \\
\hline \multirow{2}{*}{$\begin{array}{l}\text { Alumina Production } \\
\text { (Bayer) }\end{array}$} & & kgce/t & GJ/t & kgce/t & GJ/t \\
\hline & Digesting (fuel) & 414 & 12.1 & & \\
\cline { 2 - 6 } & Calcining Kiln (fuel) & 223 & 6.5 & & \\
\cline { 2 - 6 } & Electricity & 145 & 4.3 & & \\
\hline Anode Manufacture & Fuel & 35 & 1.0 & & \\
\hline & Electricity & 22 & 0.64 & & \\
\hline Aluminium Smelting (Electrolysis) & Electricity & 5064 & 148.4 & & \\
\hline Ingot Casting & Electricity & 36 & 1.06 & & $\mathbf{2 5 9}$ \\
\hline Total & & $\mathbf{5 9 4 0}$ & $\mathbf{1 7 4 . 0}$ & $\mathbf{2 5 9}$ \\
\hline
\end{tabular}

Note: Primary energy includes electricity generation, transmission, and distribution losses of $67 \%$. 


\subsubsection{Alumina Production}

Bauxite ore ${ }^{17}$ is converted to alumina through the Bayer process, whereby the ore is crushed and dissolved in a hot sodium hydroxide solution. Iron oxides and other oxides are removed as insoluble "red mud" and the solution is precipitated and then calcined to produce anhydrous alumina. The Bayer process is energy-intensive, especially the digestion and calcination processes. Calcination can be done in rotary or stationary kilns. The resulting alumina is cooled in rotary or satellite coolers, or fluidized bed coolers.

Electricity and fuel account for an average of $13 \%$ and $85 \%$ of total energy, respectively. Best practice electricity use of an alumina plant is estimated to be $203 \mathrm{kWh} / \mathrm{t}(24.9$ kgce/t) alumina or $391 \mathrm{kWh} / \mathrm{t}$ (48 kgce/t) aluminium assuming $1.925 \mathrm{t}$ alumina equals $1 \mathrm{t}$ aluminium. Energy use for digesting can vary between 6.3 and 12.6 GJ/t (215 and 430 kgce/t) alumina or 12.1 and $24.3 \mathrm{GJ} / \mathrm{t}$ (414 and $828 \mathrm{kgce} / \mathrm{t}$ ) aluminium, while the fuel consumption for the calcining kiln will vary from $3.4 \mathrm{GJ} / \mathrm{t}$ to $4.2 \mathrm{GJ} / \mathrm{t}$ (116 to $143 \mathrm{kgce} / \mathrm{t}$ ) alumina or 6.5 to $8.1 \mathrm{GJ} / \mathrm{t}$ (223 to $276 \mathrm{kgce} / \mathrm{t}$ ) aluminium. ${ }^{18}$

For the best practice alumina Bayer plant for alumina production, total fuel consumption of $9.7 \mathrm{GJ} / \mathrm{t}$ (331 kgce/t) alumina or $18.7 \mathrm{GJ} / \mathrm{t}$ (637 kgce/t) aluminium and electricity consumption of $203 \mathrm{kWh} / \mathrm{t}$ alumina, for a total consumption of $10.4 \mathrm{GJ} / \mathrm{t}$ (356 kgce/t) alumina or $20.1 \mathrm{GJ} / \mathrm{t}$ (685 kgce/t) aluminium is assumed.

\subsubsection{Anode Manufacture}

The most energy-efficient aluminum electrolysis process uses pre-baked anodes. While research is ongoing in the development of inert anodes (consisting of Titanium boride, $\mathrm{TiB}_{2}$ ) these technologies are not yet commercially used. Hence this report assumes that best practice is pre-baked carbon anodes.

Anodes are produced by heating ground and pressed tar pitch or coke from refineries at high temperatures in gas-heated furnaces. Anodes can be produced onsite at the smelter or in separate plants specialized in the manufacture of carbon anodes for various industries and applications.

The furnaces can be fired with any fuel. In most countries natural gas is used as fuel. The specific fuel consumption for anode production is estimated to be $2.45 \mathrm{GJ} / \mathrm{t}$ (84 kgce/t) anode and $140 \mathrm{kWh} / \mathrm{t}$ anode. ${ }^{19,} 20$ The most efficient smelters consume $400-440 \mathrm{~kg}$ of

\footnotetext{
${ }^{17}$ Best practice energy use is also determined by the concentration and quality of the ore used; it is assumed that all plants have access to similar qualities of raw materials.

${ }^{18}$ Worrell, E. and de Beer, J., 1991. Energy Requirements in Relation to Prevention and Re-Use of Waste Streams. Report: (in Dutch). Utrecht, The Netherlands: Novem.

${ }^{19}$ International Aluminium Institute (2003). Lifecycle Assessment of Aluminium: Inventory Data for the Worldwide Primary Aluminium Industry.

${ }^{20}$ Worrell, E. and de Beer, J., 1991. Energy Requirements in Relation to Prevention and Re-Use of Waste Streams. Report: Aluminium (in Dutch). Utrecht, The Netherlands: Novem.
} 
anode per tonne of aluminium. ${ }^{21}$ Assuming $0.42 \mathrm{t}$ anode to produce $1 \mathrm{t}$ aluminium, fuel consumption is $1.0 \mathrm{GJ} / \mathrm{t}$ (35 kgce/t) aluminium and electricity consumption is $0.21 \mathrm{GJ} / \mathrm{t}$ (7 kgce/t) aluminium for a total consumption for anode manufacture of $1.2 \mathrm{GJ} / \mathrm{t}$ (42 kgce/t) aluminium.

\subsubsection{Aluminum Smelting (Electrolysis)}

The Hall-Heroult process serves as the basis for commercial aluminum smelting. The aluminum industry currently uses two types of smelting technology: cells with prebaked anodes and cells with baked-in-situ anodes (Søderberg). Over the years five aluminum smelter types have become widespread:

In-situ (Søderberg):

- $\quad$ Vertical Stud Søderberg (VSS)

- Horizontal Stud Søderberg (HSS).

Pre-baked:

- $\quad$ Point Feed Prebake (PFPB)

- $\quad$ Center Feed Prebake (CFPB)

- $\quad$ Side Work Prebake (SWPB).

Søderberg cell plants are more energy-intensive and environmentally problematic than plants that use prebaked cells, and are hence not considered best practice. The best practice technology is a Center-Feed Prebaked (CFBP) cell. The current best practice CFPB designs use 300-315 kA currents (current densities of $0.8-0.85 \mathrm{~A} / \mathrm{cm}^{2}$ ), and consume $400-440 \mathrm{~kg}$ anode/t aluminium. ${ }^{22}$

The lowest theoretical energy requirement for electrolysis is 6,360 kWh per $\mathrm{t}$ of aluminium roduct. ${ }^{23,24}$ However, no current cell design comes close to the thermodynamic minimum. The current best practice of Hall-Heroult electrolysis cells (using currents of 300-315 kA) is estimated to be 12.9 to $13.0 \mathrm{MWh} / \mathrm{t}$ aluminium. Losses of rectifiers, auxillaries, and pollution control demand an additional $0.7-1.0 \mathrm{MWh} / \mathrm{t}$ primary aluminum. Hence, the total best practice energy consumption of the aluminum smelter is estimated to be $13.6 \mathrm{MWh} / \mathrm{t}$ or $49 \mathrm{GJ} / \mathrm{t}$ (1671 kgce/t) aluminium, including all utilities.

\subsubsection{Ingot Casting}

The molten aluminium is most often cast into ingots. Ingot casting also allows the aluminium to be alloyed with other metals to produce a specific alloy. Ingots can have various shapes and forms (e.g. slabs, rolls, bars, and blocks). After casting the ingots are

\footnotetext{
${ }^{21}$ European Commission. Integrated Pollution Prevention \& Control: Reference Document on Best Available Techniques in the Non-Ferrous Metals Industries. Brussels/Sevilla, December 2001.

${ }^{22}$ European Commission. Integrated Pollution Prevention \& Control: Reference Document on Best Available Techniques in the Non-Ferrous Metals Industries. Brussels/Sevilla, December 2001.

${ }^{23}$ Choate, W.T., Green, J.A.S., 2003. U.S. Energy Requirements for Aluminum Production: Historical Perspectives, Theoretical Limits and New Opportunities. Washington DC: BCS, Inc.

24 Beck, T.R., 2001.”Electrolytic Production of Aluminum,” Electrochemistry Encyclopedia Electrochemical Technology Corp. (http://electrochem.cwru.edu/ed/encycl/art-a01-al-prod.htm)
} 
cooled and transported to the end user. The end user may process the ingots to the final product through casting and rolling (e.g. sheets, castings).

Alloying takes place in a furnace. The furnace can be heated by fuel or electrically. Best practice electricity use is estimated to be $0.35 \mathrm{GJ} / \mathrm{t}$ (12 kgce/t) aluminium ingot, assuming direct casting with aluminium transferred hot to the alloying furnace. ${ }^{25}$ In practice, energy consumption will depend on the aluminium temperature, holding time and casting sequence.

\subsubsection{Secondary Aluminium Production}

Secondary smelting of aluminium using scrap only requires roughly $5 \%$ of the energy of primary smelting due to the relatively low melting temperature of $700-800{ }^{\circ} \mathrm{C}$. Secondary aluminium may not be suitable for all applications because the purity of the product is harder to control since the scrap may consist of many different alloying elements, and some elements are hard to remove.

Various technologies are used to recycle aluminium scrap, including reverbatory and induction furnaces. A number of new and emerging technologies are being investigated including rotary arc and plasma furnaces. The choice of the most appropriate technology will depend in the scrap to be used.

The theoretical energy consumption for aluminium melting is $1.1 \mathrm{GJ} / \mathrm{t}$ (38 kgce/t). However, no melting furnace comes close to this level. The best practice assumes a natural gas fired reverbatory furnace. Reverbatory furnaces consume between 3 and 9 GJ/t (102 and 307 kgce/t) of fuel. For the best practice performance a large reverbatory furnace using recuperative burners and state-of-the-art computer controls, consuming 2.5 GJ (85 kgce) of natural gas/t aluminium (Flannagan, 1993), is assumed. ${ }^{26}$

\footnotetext{
${ }^{25}$ International Aluminium Institute (2003). Lifecycle Assessment of Aluminium: Inventory Data for the Worldwide Primary Aluminium Industry.

${ }^{26}$ Flannagan, J.M., 1993. Process Heating in the Metals Industry. Sittard, The Netherlands: IEA-Caddet.
} 


\subsection{Cement}

Best practice values for each step of the cement making process - raw materials preparation (limestone and fuels), clinker making (fuel use and electricity use), additive drying, finish grinding and, where applicable, other production energy, which includes quarrying, auxiliaries, conveyors and packaging - are provided for final energy in Tables 2.3.1 to 2.3.3 and for primary energy in Tables 2.3.4 to 2.3.5. Other non-production energy (lighting, office equipment, etc.) is based on production throughput and a study done by Warshawsky (1996). ${ }^{27}$

Because clinker making accounts for the most energy consumed in the cement making process (about 90\%), reducing the ratio of clinker to final cement produced by mixing clinker with additives can greatly reduce the energy used for manufacture of cement. Best practice values for additive use are based on the following European ENV 197-2 standards: for composite Portland cements (CEM II), up to 35\% can be fly ash and 65\% clinker; for blast furnace slag cements (CEM III/A), up to 65\% can be blast furnace slag and $35 \%$ clinker. ${ }^{28}$ Examples of three types of cement (Portland cement, fly ash cement and blast furnace slag cements) are given in Tables 2.3.1 to 2.3.6 for final and primary energy consumption.

\subsubsection{Raw Materials and Fuel Preparation}

Energy used in preparing the raw material consists of crushing, grinding and drying (if necessary) the raw meal which is mostly limestone. Solid fuels input to the kiln must also be crushed, ground, and dried. Best practice for raw materials preparation is based on integrated vertical roller mill systems, with electricity consumption of $13-14 \mathrm{kWh} / \mathrm{t}$ raw meal for dry process kilns (for crushing and grinding only). ${ }^{29}$ Ideally this value should take into account the differences in moisture content of the raw materials as well as the hardness of the limestone. Higher moisture content requires more energy for drying and harder limestone requires more crushing and grinding energy. If drying is required, best practice is to install a preheater to dry the raw materials, which decreases the efficiency of the kiln. For this analysis, it is assumed that pre-heating of wet raw materials is negligible and does not decrease the efficiency of the kiln.

Solid fuel preparation also depends on the moisture content of the fuel. It is assumed that only coal needs to be dried and ground and that the energy required for drying or grinding of other materials is insignificant or unnecessary. Best practice is to use the waste heat from the kiln system, e.g., the clinker cooler (if available) to dry the coal. ${ }^{30}$ It is assumed that for crushing and grinding, a vertical roller or ring ball mill is more efficient than other mills (e.g., a roller mill) and uses approximately 18 to $20 \mathrm{kWh} / \mathrm{t}$ fuel. ${ }^{31}$

\footnotetext{
${ }^{27}$ Warshawsky, J. of CMP. 1996. TechCommentary: Electricity in Cement Production. EPRI Center for Materials Production, Carnegie Mellon Research Institute, Pittsburgh, PA.

${ }^{28} \mathrm{CEM}$ I is Portland cement, set at $\leq 5 \%$ additives, 95\% clinker.

${ }^{29}$ Cembureau, 1997. Best Available Techniques for the Cement Industry, Brussels: Cembureau.

${ }^{30}$ Worrell, E. and Galitsky, C., 2004. Energy Efficiency Improvement Opportunities for Cement Making: An ENERGY STAR ${ }^{\circledR}$ Guide for Energy and Plant Managers. Berkeley, CA: Lawrence Berkeley National Laboratory (LBNL-54036).

${ }^{31}$ Cembureau, 1997. Best Available Techniques for the Cement Industry, Brussels: Cembureau.
} 
Table 2.3.1. World Best Practice Final Energy Intensity Values for Portland Cement with 5\% Additives

\begin{tabular}{|c|c|c|c|c|c|c|c|c|c|c|c|}
\hline & & $\begin{array}{l}\text { Product } \\
\text { unit }\end{array}$ & $\begin{array}{c}\mathbf{k W h} / \mathbf{t} \\
\text { product }\end{array}$ & $\begin{array}{c}\text { kgce/t } \\
\text { product }\end{array}$ & $\begin{array}{c}\mathbf{G J} / \mathbf{t} \\
\text { product }\end{array}$ & $\begin{array}{l}\text { kWh/t } \\
\text { clinker }\end{array}$ & $\begin{array}{c}\text { kgce/t } \\
\text { clinker }\end{array}$ & $\begin{array}{c}\text { GJ/t } \\
\text { clinker }\end{array}$ & $\begin{array}{c}\text { kWh/t } \\
\text { cement }\end{array}$ & $\begin{array}{c}\text { kgce/t } \\
\text { cement }\end{array}$ & $\begin{array}{c}\text { GJ/t } \\
\text { cement }\end{array}$ \\
\hline Raw Materials Preparation & Electricity & t raw meal & 13 & 1.6 & 0.05 & 23.0 & 2.83 & 0.08 & 22 & 2.7 & 0.08 \\
\hline Solid Fuels Preparation & Electricity & t coal & 18 & 2.2 & 0.06 & 1.75 & 0.22 & 0.01 & 1.8 & 0.22 & 0.01 \\
\hline \multirow[t]{2}{*}{ Clinker Making } & Fuel & t clinker & & & & & 97 & 2.85 & & 92 & 2.71 \\
\hline & Electricity & t clinker & & & & 22.5 & 2.8 & 0.08 & 21.4 & 2.63 & 0.08 \\
\hline \multirow[t]{2}{*}{ Additives Preparation } & Fuel & $\mathrm{t}$ additive & & 26 & 0.75 & & & & & & \\
\hline & Electricity & $\mathrm{t}$ additive & 55 & 6.8 & 0.20 & & & & & & \\
\hline \multicolumn{12}{|l|}{ Finish Grinding } \\
\hline 325 cement & Electricity & t cement & & & & & & & 25 & 3.1 & 0.09 \\
\hline 425 cement & Electricity & t cement & & & & & & & 27 & 3.3 & 0.10 \\
\hline 525 cement & Electricity & t cement & & & & & & & 30 & 3.7 & 0.11 \\
\hline 625 cement & Electricity & t cement & & & & & & & 31 & 3.8 & 0.11 \\
\hline \multicolumn{12}{|l|}{ Total } \\
\hline 325 cement & & t cement & & & & & & & 70 & 101.0 & 2.959 \\
\hline 425 cement & & t cement & & & & & & & 72 & 101.2 & 2.967 \\
\hline 525 cement & & t cement & & & & & & & 75 & 101.6 & 2.977 \\
\hline 625 cement & & t cement & & & & & & & 76 & 101.7 & 2.981 \\
\hline
\end{tabular}

Notes: all values in final energy. Assumes ratio of $1.77 \mathrm{t}$ raw materials per t clinker; ratio of coal to clinker is 0.097 for Portland cement; ratio of additives to cement is 0.05 for Portland cement; clinker to cement ratio is 0.95 for Portland cement. Electricity required for grinding and blending additives (in addition to the electricity required to blend and grind into final product) varies depending on the material ground. See text for more details. 
Table 2.3.2. World Best Practice Final Energy Intensity Values for Fly Ash Cement with $25 \%$ Fly Ash

\begin{tabular}{|c|c|c|c|c|c|c|c|c|c|c|c|}
\hline & & $\begin{array}{l}\text { Product } \\
\text { unit }\end{array}$ & $\begin{array}{l}\mathbf{k W h} / \mathbf{t} \\
\text { product }\end{array}$ & $\begin{array}{c}\text { kgce/t } \\
\text { product }\end{array}$ & $\begin{array}{c}\text { GJ/t } \\
\text { product }\end{array}$ & $\begin{array}{l}\mathbf{k W h} / \mathrm{t} \\
\text { clinker }\end{array}$ & $\begin{array}{l}\text { kgce/t } \\
\text { clinker }\end{array}$ & $\begin{array}{c}\text { GJ/t } \\
\text { clinker }\end{array}$ & $\begin{array}{l}\mathbf{k W h} / \mathbf{t} \\
\text { cement }\end{array}$ & $\begin{array}{l}\text { kgce/t } \\
\text { cement }\end{array}$ & $\begin{array}{c}\text { GJ/t } \\
\text { cement }\end{array}$ \\
\hline Raw Materials Preparation & Electricity & t raw meal & 13 & 1.6 & 0.05 & 23.0 & 2.8 & 0.1 & 17.3 & 2.1 & 0.06 \\
\hline Solid Fuels Preparation & Electricity & t coal & 18 & 2.2 & 0.06 & & & & 1.8 & 0.2 & 0.01 \\
\hline \multirow[t]{2}{*}{ Clinker Making } & Fuel & $\mathrm{t}$ clinker & & & & & 97 & 2.85 & & 73 & 2.1 \\
\hline & Electricity & t clinker & & & & 22.5 & 2.8 & 0.08 & 16.9 & 2.07 & 0.06 \\
\hline \multirow[t]{2}{*}{ Additives Preparation } & Fuel & $\mathrm{t}$ additive & & 0 & 0.00 & & & & & 0.0 & 0.0 \\
\hline & Electricity & $\mathrm{t}$ additive & 55 & 6.8 & 0.20 & & & & 11.0 & 1.35 & 0.12 \\
\hline \multicolumn{12}{|l|}{ Finish Grinding } \\
\hline 325 cement & Electricity & t cement & & & & & & & 31 & 3.8 & 0.11 \\
\hline 425 cement & Electricity & $\mathrm{t}$ cement & & & & & & & 33 & 4.1 & 0.12 \\
\hline 525 cement & Electricity & t cement & & & & & & & 37 & 4.6 & 0.13 \\
\hline 625 cement & Electricity & t cement & & & & & & & 38 & 4.7 & 0.14 \\
\hline \multicolumn{12}{|l|}{ Total } \\
\hline 325 cement & & t cement & & & & & & & 67 & 82.5 & 2.497 \\
\hline 425 cement & & t cement & & & & & & & 69 & 82.8 & 2.506 \\
\hline 525 cement & & $\mathrm{t}$ cement & & & & & & & 73 & 83.3 & 2.519 \\
\hline 625 cement & & t cement & & & & & & & 74 & 83.4 & 2.524 \\
\hline
\end{tabular}

Notes: all values in final energy. Assumes ratio of $1.77 \mathrm{t}$ raw materials per t clinker; ratio of coal to clinker is 0.003 for fly ash cement; ratio of additives to cement is 0.25 for fly ash cement ( $5 \%$ is gypsum and anhydrites; $20 \%$ is fly ash); clinker to cement ratio is 0.75 for fly ash cement. Electricity required for grinding and blending additives (in addition to the electricity required to blend and grind into final product) varies depending on the material ground. See text for more details. 
Table 2.3.3. World Best Practice Final Energy Intensity Values for Blast Furnace Slag Cement with 65\% Blast Furnace Slag

\begin{tabular}{|c|c|c|c|c|c|c|c|c|c|c|c|}
\hline & & $\begin{array}{l}\text { Product } \\
\text { unit }\end{array}$ & $\begin{array}{l}\mathbf{k W h} / \mathbf{t} \\
\text { product }\end{array}$ & $\begin{array}{c}\text { kgce/t } \\
\text { product }\end{array}$ & $\begin{array}{c}\text { GJ/t } \\
\text { product }\end{array}$ & $\begin{array}{l}\mathbf{k W h} / \mathrm{t} \\
\text { clinker }\end{array}$ & $\begin{array}{l}\text { kgce/t } \\
\text { clinker }\end{array}$ & $\begin{array}{c}\text { GJ/t } \\
\text { clinker }\end{array}$ & $\begin{array}{l}\mathbf{k W h} / \mathbf{t} \\
\text { cement }\end{array}$ & $\begin{array}{l}\text { kgce/t } \\
\text { cement }\end{array}$ & $\begin{array}{c}\text { GJ/t } \\
\text { cement }\end{array}$ \\
\hline Raw Materials Preparation & Electricity & t raw meal & 13 & 1.6 & 0.05 & 23.01 & 2.83 & 0.08 & 21.9 & 2.7 & 0.08 \\
\hline Solid Fuels Preparation & Electricity & t coal & 18 & 2.2 & 0.06 & & & & 1.8 & 0.2 & 0.01 \\
\hline \multirow[t]{2}{*}{ Clinker Making } & Fuel & $\mathrm{t}$ clinker & & & & & 97.3 & 2.85 & & 34.0 & 1.00 \\
\hline & Electricity & t clinker & & & & 23 & 2.8 & 0.08 & 7.9 & 1.0 & 0.03 \\
\hline \multirow[t]{2}{*}{ Additives Preparation } & Fuel & $\mathrm{t}$ additive & & 26 & 0.75 & & & & & 15.30 & 0.45 \\
\hline & Electricity & $\mathrm{t}$ additive & 55 & 6.8 & 0.20 & & & & 33.0 & 4.1 & 0.1 \\
\hline \multicolumn{12}{|l|}{ Finish Grinding } \\
\hline 325 cement & Electricity & t cement & & & & & & & 58 & 7.1 & 0.21 \\
\hline 425 cement & Electricity & $\mathrm{t}$ cement & & & & & & & 62 & 7.7 & 0.22 \\
\hline 525 cement & Electricity & t cement & & & & & & & 69 & 8.5 & 0.25 \\
\hline 625 cement & Electricity & t cement & & & & & & & 72 & 8.8 & 0.26 \\
\hline \multicolumn{12}{|l|}{ Total } \\
\hline 325 cement & & t cement & & & & & & & 89 & 64.4 & 1.886 \\
\hline 425 cement & & t cement & & & & & & & 94 & 64.9 & 1.903 \\
\hline 525 cement & & $\mathrm{t}$ cement & & & & & & & 101 & 65.8 & 1.928 \\
\hline 625 cement & & t cement & & & & & & & 103 & 66.1 & 1.936 \\
\hline
\end{tabular}

Notes: all values in final energy. Assumes ratio of $1.77 \mathrm{t}$ raw materials per t clinker; ratio of coal to clinker is 0 for blast furnace slag cement; ratio of additives to cement is 0.65 for blast furnace slag cement (5\% is gypsum or anhydrites; $60 \%$ is slags); clinker to cement ratio is 0.35 for blast furnace slag cement. Electricity required for grinding and blending additives (in addition to the electricity required to blend and grind into final product) varies depending on the material ground. See text for more details. 
Table 2.3.4. World Best Practice Primary Energy Intensity Values for Portland Cement with 5\% Additives

\begin{tabular}{|c|c|c|c|c|c|c|c|c|c|c|c|}
\hline & & $\begin{array}{l}\text { Product } \\
\text { unit }\end{array}$ & $\begin{array}{l}\mathbf{k W h} / \mathbf{t} \\
\text { product }\end{array}$ & $\begin{array}{l}\text { kgce/t } \\
\text { product }\end{array}$ & $\begin{array}{c}\text { GJ/t } \\
\text { product }\end{array}$ & $\begin{array}{l}\mathbf{k W h} / \mathbf{t} \\
\text { clinker }\end{array}$ & $\begin{array}{l}\text { kgce/t } \\
\text { clinker }\end{array}$ & $\begin{array}{c}\text { GJ/t } \\
\text { clinker }\end{array}$ & $\begin{array}{l}\mathrm{kWh} / \mathrm{t} \\
\text { cement }\end{array}$ & $\begin{array}{l}\text { kgce/t } \\
\text { cement }\end{array}$ & $\begin{array}{c}\text { GJ/t } \\
\text { cement }\end{array}$ \\
\hline Raw Materials Preparation & Electricity & t raw meal & 39 & 4.8 & 0.14 & 69.7 & 8.56 & 0.25 & 66.2 & 8.1 & 0.24 \\
\hline Solid Fuels Preparation & Electricity & $\mathrm{t}$ coal & 55 & 6.7 & 0.20 & 5.31 & 0.65 & 0.02 & 5.3 & 0.65 & 0.02 \\
\hline \multirow[t]{2}{*}{ Clinker Making } & Fuel & t clinker & & & & & 97 & 2.85 & & 92 & 2.71 \\
\hline & Electricity & t clinker & & & & 68.2 & 8.4 & 0.25 & 64.8 & 7.96 & 0.23 \\
\hline \multirow[t]{2}{*}{ Additives Preparation } & Fuel & $\mathrm{t}$ additive & & 26 & 0.76 & & & & & & \\
\hline & Electricity & $\mathrm{t}$ additive & 167 & 20.5 & 0.60 & & & & & & \\
\hline \multicolumn{12}{|l|}{ Finish Grinding } \\
\hline 325 cement & Electricity & t cement & & & & & & & 76 & 9.3 & 0.27 \\
\hline 425 cement & Electricity & t cement & & & & & & & 82 & 10.1 & 0.29 \\
\hline 525 cement & Electricity & t cement & & & & & & & 91 & 11.2 & 0.33 \\
\hline 625 cement & Electricity & t cement & & & & & & & 94 & 11.5 & 0.34 \\
\hline \multicolumn{12}{|l|}{ Total } \\
\hline 325 cement & & $\mathrm{t}$ cement & & & & & & & 212 & 118.5 & 3.47 \\
\hline 425 cement & & t cement & & & & & & & 218 & 119.2 & 3.49 \\
\hline 525 cement & & t cement & & & & & & & 227 & 120.3 & 3.53 \\
\hline 625 cement & & t cement & & & & & & & 230 & 120.7 & 3.54 \\
\hline
\end{tabular}

Notes: all values in primary energy. Primary energy includes electricity generation, transmission, and distribution losses of $67 \%$. Assumes ratio of 1.77 t raw materials per t clinker; ratio of coal to clinker is 0.097 for Portland cement; ratio of additives to cement is 0.05 for Portland cement; clinker to cement ratio is 0.95 for Portland cement. Electricity required for grinding and blending additives (in addition to the electricity required to blend and grind into final product) varies depending on the material ground. See text for more details. 
Table 2.3.5. World Best Practice Primary Energy Intensity Values for Fly Ash Cement with 25\% Fly Ash

\begin{tabular}{|c|c|c|c|c|c|c|c|c|c|c|c|}
\hline & & $\begin{array}{l}\text { Product } \\
\text { unit }\end{array}$ & $\begin{array}{c}\mathbf{k W h} / \mathbf{t} \\
\text { product }\end{array}$ & $\begin{array}{c}\text { kgce/t } \\
\text { product }\end{array}$ & $\begin{array}{c}\mathbf{G J} / \mathbf{t} \\
\text { product }\end{array}$ & $\begin{array}{l}\text { kWh/t } \\
\text { clinker }\end{array}$ & $\begin{array}{c}\text { kgce/t } \\
\text { clinker }\end{array}$ & $\begin{array}{c}\text { GJ/t } \\
\text { clinker }\end{array}$ & $\begin{array}{c}\text { kWh/t } \\
\text { cement }\end{array}$ & $\begin{array}{c}\text { kgce/t } \\
\text { cement }\end{array}$ & $\begin{array}{c}\text { GJ/t } \\
\text { cement }\end{array}$ \\
\hline Raw Materials Preparation & Electricity & t raw meal & 39 & 4.8 & 0.14 & 69.7 & 8.6 & 0.3 & 52.3 & 6.4 & 0.19 \\
\hline Solid Fuels Preparation & Electricity & t coal & 55 & 6.7 & 0.20 & & & & 5.3 & 0.7 & 0.02 \\
\hline \multirow[t]{2}{*}{ Clinker Making } & Fuel & t clinker & & & & & 97 & 2.85 & & 73 & 2.1 \\
\hline & Electricity & t clinker & & & & 68.2 & 8.4 & 0.25 & 51.1 & 6.28 & 0.18 \\
\hline \multirow[t]{2}{*}{ Additives Preparation } & Fuel & $\mathrm{t}$ additive & & 0 & 0.00 & & & & & 0.00 & 0.00 \\
\hline & Electricity & $\mathrm{t}$ additive & 182 & 22.3 & 0.65 & & & & 36.4 & 4.47 & 0.39 \\
\hline \multicolumn{12}{|l|}{ Finish Grinding } \\
\hline 325 cement & Electricity & t cement & & & & & & & 94 & 11.5 & 0.34 \\
\hline 425 cement & Electricity & t cement & & & & & & & 101 & 10.1 & 0.29 \\
\hline 525 cement & Electricity & t cement & & & & & & & 113 & 11.2 & 0.33 \\
\hline 625 cement & Electricity & t cement & & & & & & & 116 & 11.5 & 0.34 \\
\hline \multicolumn{12}{|l|}{ Total } \\
\hline 325 cement & & t cement & & & & & & & 203 & 102.3 & 3.26 \\
\hline 425 cement & & t cement & & & & & & & 210 & 100.8 & 3.22 \\
\hline 525 cement & & t cement & & & & & & & 221 & 101.9 & 3.25 \\
\hline 625 cement & & t cement & & & & & & & 225 & 102.3 & 3.26 \\
\hline
\end{tabular}

Notes: all values in primary energy. Primary energy includes electricity generation, transmission, and distribution losses of $67 \%$. Assumes ratio of $1.77 \mathrm{t}$ raw materials per t clinker; ratio of coal to clinker is 0.003 for fly ash cement; ratio of additives to cement is 0.25 for fly ash cement (5\% is gypsum and anhydrites; $20 \%$ is fly ash); clinker to cement ratio is 0.75 for fly ash cement. Electricity required for grinding and blending additives (in addition to the electricity required to blend and grind into final product) varies depending on the material ground. See text for more details. 
Table 2.3.6. World Best Practice Primary Energy Intensity Values for Blast Furnace Slag Cement with 65\% Blast Furnace Slag

\begin{tabular}{|c|c|c|c|c|c|c|c|c|c|c|c|}
\hline & & $\begin{array}{l}\text { Product } \\
\text { unit }\end{array}$ & $\begin{array}{l}\mathbf{k W h} / \mathbf{t} \\
\text { product }\end{array}$ & $\begin{array}{c}\text { kgce/t } \\
\text { product }\end{array}$ & $\begin{array}{c}\text { GJ/t } \\
\text { product }\end{array}$ & $\begin{array}{l}\mathbf{k W h} / \mathbf{t} \\
\text { clinker }\end{array}$ & $\begin{array}{l}\text { kgce/t } \\
\text { clinker }\end{array}$ & $\begin{array}{c}\text { GJ/t } \\
\text { clinker }\end{array}$ & $\begin{array}{l}\mathbf{k W h} / \mathbf{t} \\
\text { cement }\end{array}$ & $\begin{array}{l}\text { kgce/t } \\
\text { cement }\end{array}$ & $\begin{array}{c}\mathbf{G J} / \mathbf{t} \\
\text { cement }\end{array}$ \\
\hline Raw Materials Preparation & Electricity & $\mathrm{t}$ raw meal & 39 & 4.8 & 0.14 & 69.73 & 8.56 & 0.25 & 66.2 & 8.1 & 0.24 \\
\hline Solid Fuels Preparation & Electricity & t coal & 55 & 6.7 & 0.20 & & & & 5.3 & 0.7 & 0.02 \\
\hline \multirow[t]{2}{*}{ Clinker Making } & Fuel & t clinker & & & & & 97.3 & 2.85 & & 34.0 & 1.00 \\
\hline & Electricity & t clinker & & & & 68.2 & 8.4 & 0.25 & 23.9 & 2.9 & 0.09 \\
\hline \multirow[t]{2}{*}{ Additives Preparation } & Fuel & $\mathrm{t}$ additive & & 26.0 & 0.76 & & & & & 15.60 & 0.46 \\
\hline & Electricity & $\mathrm{t}$ additive & 242 & 29.8 & 0.87 & & & & 145.5 & 17.9 & 0.5 \\
\hline \multicolumn{12}{|l|}{ Finish Grinding } \\
\hline 325 cement & Electricity & t cement & & & & & & & 175 & 21.5 & 0.63 \\
\hline 425 cement & Electricity & $\mathrm{t}$ cement & & & & & & & 189 & 10.1 & 0.29 \\
\hline 525 cement & Electricity & t cement & & & & & & & 210 & 11.2 & 0.33 \\
\hline 625 cement & Electricity & t cement & & & & & & & 217 & 11.5 & 0.34 \\
\hline \multicolumn{12}{|l|}{ Total } \\
\hline 325 cement & & t cement & & & & & & & 271 & 100.7 & 2.95 \\
\hline 425 cement & & t cement & & & & & & & 285 & 89.3 & 2.62 \\
\hline 525 cement & & $\mathrm{t}$ cement & & & & & & & 306 & 90.4 & 2.65 \\
\hline 625 cement & & t cement & & & & & & & 313 & 90.8 & 2.66 \\
\hline
\end{tabular}

Notes: all values in primary energy. Primary energy includes electricity generation, transmission, and distribution losses of $67 \%$. Assumes ratio of $1.77 \mathrm{t}$ raw materials per t clinker; ratio of coal to clinker is 0 for blast furnace slag cement; ratio of additives to cement is 0.65 for blast furnace slag cement ( $5 \%$ is gypsum or anhydrites; $60 \%$ is slags); clinker to cement ratio is 0.35 for blast furnace slag cement. Electricity required for grinding and blending additives (in addition to the electricity required to blend and grind into final product) varies depending on the material ground. See text for more details. 


\subsubsection{Clinker Production}

Clinker production can be split into the electricity required to run the machinery, including the fans, the kiln drive, the cooler and the transport of materials to the top of the preheater tower, and the fuel needed to dry, to calcine and to clinkerize the raw materials. Best practice for clinker making mechanical requirements is estimated to be $22.5 \mathrm{kWh} / \mathrm{t}$ clinker, ${ }^{32}$ while fuel use has been reported as low as $2.85 \mathrm{GJ} / \mathrm{t}(97.3 \mathrm{kgce} / \mathrm{t})$ clinker. $^{33}$

\subsubsection{Additive Preparation}

In addition to clinker, some plants use additives in the final cement product. While this reduces the most energy intensive stage of production (clinker making), as well as the carbonation process which produces additional $\mathrm{CO}_{2}$ as a product of the reaction, additional electricity is required to blend and grind the additives, while additional fuel is required to dry some additives like blast furnace and other slags.

Additional requirements from use of additives is based on the differences between blending and grinding Portland cement ( $5 \%$ additives) and other types of cement (up to $65 \%$ additives). Portland Cement requires about $55 \mathrm{kWh} / \mathrm{t}$ for clinker grinding, while fly ash cement (with $25 \%$ fly ash) requires $60 \mathrm{kWh} / \mathrm{t}$ and blast furnace slag cement (with $65 \%$ slag) requires $80 \mathrm{kWh} / \mathrm{t} .{ }^{34}$ It is assumed that only fly ash, blast furnace and other slags and natural pozzolans need additional energy. Based on the data above, fly ash will require an additional $20 \mathrm{kWh} / \mathrm{t}$ of fly ash and slags will require an additional $38 \mathrm{kWh} / \mathrm{t}$ of slag. It is assumed that natural pozzolans have requirements similar to fly ash.

For additives which are dried, best practice requires $0.75 \mathrm{GJ} / \mathrm{t}$ (26 kgce/t) of additive. ${ }^{35}$ Generally, only blast furnace and other slags are dried.

\subsubsection{Finish Grinding}

Best practice for finish grinding depends on the cement being produced, measured as fineness or Blaine $\left(\mathrm{cm}^{2} / \mathrm{g}\right)$. Buzzi (1997) claims that the Horomill requires $25 \mathrm{kWh} / \mathrm{t}$ of cement for 3200 Blaine and $30 \mathrm{kWh} / \mathrm{t}$ cement for 4000 Blaine. ${ }^{36}$

\footnotetext{
${ }^{32}$ COWIconsult, March Consulting Group and MAIN, 1993. Energy Technology in the Cement Industrial Sector, Report prepared for CEC - DG-XVII, Brussels, April.

${ }^{33}$ Park, H. 1998. Strategies for Assessing Energy Conservation Potentials in the Korean Manufacturing Sector. In: Proceedings 1998 Seoul Conference on Energy Use in Manufacturing: Energy Savings and $\mathrm{CO}_{2}$ Mitigation Policy Analysis. 19-20 May, POSCO Center, Seoul, Republic of Korea.

${ }^{34}$ Van Heijningen, R.J.J., J.F.M de Castro and E. Worrell (ed.). 1992. Energiekentallen in relatie tot preventie en hergebruik van afvalstromen, Rapport in opdracht van Nationaal Onderzoeks Programma Hergebruik van Afvalstoffen, Utrecht/Bilthoven, February.

${ }^{35}$ E. Worrell, R.J.J. van Heijningen, J.F.M. de Castro, J.H.O. Hazewinkel, J.G. de Beer, A.P.C. Faaij and K. Vringer, "New Gross Energy-Requirement Figures for Materials Production", Energy, the International Journal 619 pp.627-640 (1994).

${ }^{36}$ Buzzi, S. 1997. Die Horomill ${ }^{\circledR}$ - Eine Neue Mühle für die Feinzerkleinerung, ZKG International 3 50: 127-138.
} 


\subsubsection{Other Production Energy}

Some cement enterprises have quarries on-site, and those generally use both trucks and conveyors to move raw materials. If applicable to the cement facility, quarrying is estimated to use about $1 \%$ of the total electricity at the facility. ${ }^{37}$

Other production energy includes power for auxiliaries, conveyors within the facility, and packaging equipment. Total power use for auxiliaries is estimated to require about 10 $\mathrm{kWh} / \mathrm{t}$ of clinker at a cement enterprise. Packaging and conveyors together are estimated to use about $5 \%$ of the total electricity at a cement enterprise; of that $5 \%$, power use for conveyors is estimated to require about 1 to $2 \mathrm{kWh} / \mathrm{t}$ of cement. ${ }^{38}$

\footnotetext{
${ }^{37}$ Warshawsky, J. of CMP. 1996. TechCommentary: Electricity in Cement Production. EPRI Center for Materials Production, Carnegie Mellon Research Institute, Pittsburgh, PA.

${ }^{38}$ Worrell, E. and Galitsky, C., 2004. Energy Efficiency Improvement Opportunities for Cement Making: An ENERGY STAR ${ }^{\circledR}$ Guide for Energy and Plant Managers. Berkeley, CA: Lawrence Berkeley National Laboratory (LBNL-54036).
} 


\subsection{Pulp and Paper}

The pulp and paper industry converts fibrous raw materials into pulp, paper, and paperboard. The processes involved in papermaking include raw materials preparation, pulping (chemical, semi-chemical, mechanical, or waste paper), bleaching, chemical recovery, pulp drying, and papermaking. The most significant energy-consuming processes are pulping and drying. Globally, wood is the main fiber source in the paper industry and most mills are quite large, producing over 300,000 t/year for typical paper mills.

International best practice energy use in pulp and papermaking technology is based on wood-based fibers. ${ }^{39}$ Hence, the identified best practice technologies may not be applicable to non-wood fiber based pulp mills. Most papermaking technology is developed and manufactured in Europe (Metso and Voith) and Japan (Mitsubishi), and specialized products from North America (e.g. felts). There is limited experience with non-wood fiber outside of China and India, with the last mills in Europe closing down (Dunavarosc in Hungary (1980s), Fredericia in Denmark (1991), and SAICA in Spain (1999) due to tightening environmental regulations. Even though there is increased interest in the use of non-wood fibers internationally, only a few best practice technologies are available. Only one "non-wood" best practice pulping technology outside China has been identified. Other clean modern non-wood pulping technology has not yet been demonstrated on commercial scales. Although the use of non-wood fibers may affect the characteristics of the pulp (e.g. runnability, water retention), it is hard to evaluate ex-ante the impact on the energy use of the paper machine. The energy use of the paper machine is generally dependent on the pulp quality and paper grade produced, and hence the best practice values apply to paper machines, indiscriminate of the source of the virgin pulp (given a specific quality). Note that the variation of the pulp characteristics and paper grades is so large, that it will affect the best practice energy intensity values.

Tables 2.4.1 and 2.4.2 provide best practice final and primary energy intensity values, respectively, for stand-alone pulp mills. Tables 2.4.3 and 2.4.4 provide best practice final and primary energy intensity values, respectively, for stand-alone paper mills. The best practice energy figures are only indicative, as energy use will depend on the specific

\footnotetext{
${ }^{39}$ China's paper industry is unique in that it is one of the largest users of non-wood fibers. In fact, the share of wood fiber used in China has declined since the 1990s to about $7 \%$ of the input of the paper production, with recovered paper representing $36 \%$, and the remaining $57 \%$ covered by imported waste paper and nonwood fiber (http://faostat.fao.org/). In the late 1990s there were over 5,000 pulp and paper mills in China, of which over $70 \%$ used non-wood fibers, mainly straw. Most non-wood fiber mills are small scale. In 1998 there were only 43 non-wood mills with a capacity exceeding 30,000 t/year, and the vast majority produced less than 10,000, or even 5,000 t/year (Ren, X., 1998. Cleaner Production in China's Pulp and Paper Industry. Journal of Cleaner Production 6 pp.349-355). Since 2000, the Chinese government has started to close down the small polluting and inefficient mills. In recent years modern large-scale paper machines have been installed in China (e.g. Hebei Norske Skog Long 300,000 t/year plant, Dagang's paper machine 3 with a capacity of 1.1 million t/year). Non-wood fibers are expected to continue to play an important role in China's future paper industry.
} 
properties of the raw materials and products. While the main factors affecting the best practice energy use are discussed, the figures should be interpreted with care. Furthermore, while the pulping and papermaking processes are discussed separately below, integration of the pulp and paper mill will result in energy savings due to the reduced need to dry pulp and opportunities to provide a better heat integration. The best practice energy intensities for the main processes and the factors affecting energy use and intensity are discussed below. Only the lime kiln in the Kraft recovery processes uses fuel. All other processes only use steam and electricity. Below energy use data is expressed as steam $(\mathrm{GJ} / \mathrm{t})$ and electricity $(\mathrm{kWh} / \mathrm{t}) .{ }^{40}$ Best practice assumes that the steam and electricity are generated in a cogeneration (combined heat and power) installation.

\subsubsection{Non-Wood Pulping}

The current international best practice is based on the Chempolis process developed in Finland. It provides a clean process that recovers the chemicals. ${ }^{41} \mathrm{~A}$ first demonstration plant with a capacity of 65,000 air dry t (ADt)/year has been designed for construction in China, but construction has been delayed. The pulp has similar characteristics as hardwood pulp, resulting in similar behavior (e.g. runnability, water retention) in the paper machine (see below).

The design assumes a steam consumption of 5 to $6 \mathrm{t} / \mathrm{ADt}$ pulp, or equivalent to approximately 10.5 to $12.6 \mathrm{GJ} / \mathrm{ADt}$ (358 to $430 \mathrm{kgce} / \mathrm{ADt}$ ) pulp. These values vary with the process lay-out. The above values assume conventional water treatment, and exclude pulp drying (for preparation of market pulp). Electricity consumption is estimated to be $400 \mathrm{kWh} / \mathrm{ADt}$. Note that the process uses no fuel directly, as there is no need for a calcination kiln (as with kraft pulping). ${ }^{42}$

The lignin generates steam of about 7 to $9 \mathrm{t} / \mathrm{ADt}$ pulp, depending on the lignin yield, required steam pressure and feed water temperature. Hence, the plant can have an excess steam production of 2 to $3 \mathrm{t} / \mathrm{ADt}$, equivalent to approximately 4.2 to $6.3 \mathrm{GJ} / \mathrm{ADt}$ (143 to $215 \mathrm{kgce} / \mathrm{ADt}$ ) that can be exported for use in the paper machine. ${ }^{43}$

\footnotetext{
${ }^{40}$ Energy use in the paper industry is typically expressed per tonne of air dried material (ADt).

${ }^{41}$ Anttila, J.R., P.P. Rousu, P. Rousu, K.J.E. Hytonen and J.P. Tanskanen. 2006. Design of an Environmentally Benign Non-wood Pulp Plant. Chempolis.

${ }^{42}$ Rousu, P. 2006. Personal communication from Pasi Rousu, Chempolis, Finland. August 16th, 2006.

${ }^{43}$ Rousu, P., P. Rousu and J. Antila. 2002. Sustainable Pulp Production form Agricultural Waste. Resources, Conservation \& Recycling 35 pp.85-103.
} 
Table 2.4.1. World Best Practice Final Energy Intensity Values for Stand-Alone Pulp Mills (values are per air dried metric tons). ${ }^{44,} 45$

\begin{tabular}{|l|l|l|c|c|c|c|c|c|c|c|}
\hline \multirow{2}{*}{$\begin{array}{l}\text { Raw } \\
\text { Material }\end{array}$} & Product & Process & \multicolumn{2}{|c|}{ Fuel Use for Steam } & \multicolumn{2}{|c|}{ Steam Exported } & \multicolumn{2}{|c|}{$\begin{array}{c}\text { Electricity } \\
\text { Use }\end{array}$} & $\begin{array}{c}\text { Electricity } \\
\text { Produced }\end{array}$ & \multicolumn{2}{|c|}{ Total } \\
\cline { 4 - 11 } & & & GJ/ADt & kgce/Adt & GJ/Adt & kgce/Adt & kWh/Adt & kWh/Adt & GJ/Adt & kgce/Adt \\
\hline Non-wood & Market Pulp & Pulping & 10.5 & 358 & -4.2 & -143 & 400 & & 7.7 & 264 \\
\hline Wood & Market Pulp & Kraft & 11.2 & 382 & & & 640 & -655 & 11.1 & 380 \\
\hline & & Sulfite & 16 & 546 & & & 700 & & 18.5 & 632 \\
\hline & & Thermo-mechanical & & & -1.3 & -45 & 2190 & & 6.6 & 224 \\
\hline Paper & Recovered Pulp & & 0.3 & 10 & & & 330 & & 1.5 & 51 \\
\hline
\end{tabular}

Table 2.4.2. World Best Practice Primary Energy Intensity Values for Stand-Alone Pulp Mills (values are per air dried metric tons). ${ }^{46,47}$

\begin{tabular}{|c|c|c|c|c|c|c|c|c|c|c|}
\hline \multirow{2}{*}{$\begin{array}{l}\text { Raw } \\
\text { Material }\end{array}$} & \multirow[t]{2}{*}{ Product } & \multirow[t]{2}{*}{ Process } & \multicolumn{2}{|c|}{ Fuel Use for Steam } & \multicolumn{2}{|c|}{ Steam Exported } & \multirow{2}{*}{$\begin{array}{c}\text { Electricity } \\
\text { Use }\end{array}$} & \multirow{2}{*}{$\begin{array}{r}\begin{array}{r}\text { Electricity } \\
\text { Produced }\end{array} \\
\text { kWh/Adt }\end{array}$} & \multicolumn{2}{|c|}{ Total } \\
\hline & & & GJ/ADt & kgce/Adt & GJ/Adt & kgce/Adt & & & GJ/Adt & kgce/Adt \\
\hline Non-wood & Market Pulp & Pulping & 10.5 & 358 & -4.2 & -143 & 1212 & & 10.7 & 364 \\
\hline \multirow{3}{*}{ Wood } & Market Pulp & Kraft & 11.2 & 382 & & & 1939 & -1985 & 11.0 & 377 \\
\hline & & Sulfite & 16 & 546 & & & 2121 & & 23.6 & 807 \\
\hline & & Thermo-mechanical & & & -1.3 & -45 & 6636 & & 22.6 & 770 \\
\hline Paper & Recovered Pulp & & 0.3 & 10 & & & 1000 & & 3.9 & 133 \\
\hline
\end{tabular}

Note: Primary energy includes electricity generation, transmission, and distribution losses of $67 \%$.

\footnotetext{
${ }^{44}$ IPPC, 2001. Reference Document on Best Available Techniques in the Pulp and Paper Industries. Integrated Pollution Prevention \& Control. European Commission, Brussels/Sevilla, 2001.

${ }^{45}$ Francis, D.W., M.T. Towers, T.C. Browne. 2002. Energy Cost Reduction in the Pulp and Paper Industry: An Energy Benchmarking Perspective. Ottawa: NRCan.

${ }^{46}$ IPPC, 2001. Reference Document on Best Available Techniques in the Pulp and Paper Industries. Integrated Pollution Prevention \& Control. European Commission, Brussels/Sevilla, 2001.

${ }^{47}$ Francis, D.W., M.T. Towers, T.C. Browne. 2002. Energy Cost Reduction in the Pulp and Paper Industry: An Energy Benchmarking Perspective. Ottawa: NRCan.
} 
Table 2.4.3. World Best Practice Final Energy Intensity Values for Stand-Alone Paper Mills (values are per air dried metric tons). ${ }^{4}$

$48,49,50$

\begin{tabular}{|c|c|c|c|c|c|c|c|}
\hline \multirow[t]{2}{*}{ Raw Material } & \multirow[t]{2}{*}{ Product } & \multirow[t]{2}{*}{ Process } & \multicolumn{2}{|c|}{ Fuel Use for Steam } & \multirow{2}{*}{$\begin{array}{c}\text { Electricity Use } \\
\text { kWh/ADt } \\
\end{array}$} & \multicolumn{2}{|c|}{ Total } \\
\hline & & & GJ/ADt & kgce/Adt & & GJ/Adt & kgce/ADt \\
\hline \multirow[t]{6}{*}{ Pulp } & Uncoated Fine (wood free) & Paper Machine & 6.7 & 229 & 640 & 9.0 & 307 \\
\hline & Coated Fine (wood free) & Paper Machine & 7.5 & 256 & 810 & 10.4 & 355 \\
\hline & Newsprint & Paper Machine & 5.1 & 174 & 570 & 7.2 & 244 \\
\hline & Board & Paper Machine & 6.7 & 229 & 800 & 9.6 & 327 \\
\hline & Kraftliner & Paper Machine & 5.9 & 201 & 535 & 7.8 & 267 \\
\hline & Tissue & Paper Machine & 6.9 & 235 & 1000 & 10.5 & 358 \\
\hline
\end{tabular}

Table 2.4.4. World Best Practice Primary Energy Intensity Values for Stand-Alone Paper Mills (values are per air dried metric tons). ${ }^{51,52,53}$

\begin{tabular}{|c|c|c|c|c|c|c|c|}
\hline \multirow[t]{2}{*}{ Raw Material } & \multirow[t]{2}{*}{ Product } & \multirow[t]{2}{*}{ Process } & \multicolumn{2}{|c|}{ Fuel Use for Steam } & \multirow{2}{*}{$\begin{array}{c}\text { Electricity Use } \\
\text { kWh/ADt } \\
\end{array}$} & \multicolumn{2}{|c|}{ Total } \\
\hline & & & GJ/ADt & kgce/Adt & & GJ/Adt & kgce/ADt \\
\hline \multirow[t]{6}{*}{ Pulp } & Uncoated Fine (wood free) & Paper Machine & 6.7 & 229 & 1939 & 13.7 & 467 \\
\hline & Coated Fine (wood free) & Paper Machine & 7.5 & 256 & 2455 & 16.3 & 558 \\
\hline & Newsprint & Paper Machine & 5.1 & 174 & 1727 & 11.3 & 386 \\
\hline & Board & Paper Machine & 6.7 & 229 & 2424 & 15.4 & 527 \\
\hline & Kraftliner & Paper Machine & 5.9 & 201 & 1621 & 11.7 & 401 \\
\hline & Tissue & Paper Machine & 6.9 & 235 & 3030 & 17.8 & 608 \\
\hline
\end{tabular}

Note: Primary energy includes electricity generation, transmission, and distribution losses of $67 \%$.

${ }^{48}$ IPPC, 2001. Reference Document on Best Available Techniques in the Pulp and Paper Industries. Integrated Pollution Prevention \& Control. European Commission, Brussels/Sevilla, 2001.

${ }^{49}$ Karlsson, M., 2005. The Dutch Innovation Transition, Small/Large Paper/Board Machine Concepts, Automation. Presentation at Meeting of the Royal Netherlands Paper and Board Industry Association (VNP), Beekbergen, The Netherlands, February $23^{\text {rd }}, 2005$.

${ }^{50}$ Francis, D.W., M.T. Towers, T.C. Browne. 2002. Energy Cost Reduction in the Pulp and Paper Industry: An Energy Benchmarking Perspective. Ottawa: NRCan.

${ }^{51}$ IPPC, 2001. Reference Document on Best Available Techniques in the Pulp and Paper Industries. Integrated Pollution Prevention \& Control. European Commission, Brussels/Sevilla, 2001.

${ }^{52}$ Karlsson, M., 2005. The Dutch Innovation Transition, Small/Large Paper/Board Machine Concepts, Automation. Presentation at Meeting of the Royal Netherlands Paper and Board Industry Association (VNP), Beekbergen, The Netherlands, February $23^{\text {rd }}, 2005$.

${ }^{53}$ Francis, D.W., M.T. Towers, T.C. Browne. 2002. Energy Cost Reduction in the Pulp and Paper Industry: An Energy Benchmarking Perspective. Ottawa: NRCan. 


\subsubsection{Kraft Pulping}

A best practice Kraft mill produces excess electricity that can be exported. The export is the result of balancing the energy used in the pulping process and the energy recovered from the black liquor recovery process (combusting the lignin). The energy consumption of the process itself varies between 10 and 12.2 GJ/ADt (341-416 kgce/ADt) pulp, while electricity use is around $610 \mathrm{kWh} / \mathrm{ADt}(75 \mathrm{kgce} / \mathrm{ADt})$. The lime kiln uses $1.2 \mathrm{GJ} / \mathrm{ADt}$ in fuels and $30 \mathrm{kWh} / \mathrm{ADt}^{54}$ for total energy consumption of $11.2 \mathrm{GJ} / \mathrm{ADt}$ (382 kgce/ADt) in fuels and $640 \mathrm{kWh} / \mathrm{ADt}$ in electricity.

However, the recovery process is a net producer of $15.8 \mathrm{GJ} / \mathrm{ADt}$ of steam. It is assumed that the steam is used in a back-pressure steam turbine to generate electricity (around 655 $\mathrm{kWh} / \mathrm{ADt}$ ), resulting in a net export of power of 15 to $20 \mathrm{kWh} / \mathrm{ADt}$. This leads to a total overall energy consumption value of $11.1 \mathrm{GJ} / \mathrm{ADt}$ (380 kgce).

Research and development in black liquor gasification has not yet resulted in a commercially operating process, and is hence not included in the best practice energy consumption figures. However, when this technology is available it could result in significant energy savings, due to large amounts of excess power production.

\subsubsection{Sulfite Pulping}

Sulfite pulping is used much less than Kraft pulping, and mainly used for specialty papers. Also, most of the sulfite pulp is bleached. The wood is cooked using a solution of sulfur dioxide with an alkaline solution. The process can be operated to produce a wide range of specialty products, which will also result in a wide range of energy use. Energy can be recovered from the "green liquor", similar to the black liquor recovery process, producing about $15 \mathrm{GJ} / \mathrm{ADt}$ (512 kgce/ADt) pulp. The best practice assumes optimization of power use, state-of-the-art controls, efficient evaporation and concentration of the green liquor. Due to the variety of pulps to be produced, steam use is estimated to be 16 to $18 \mathrm{GJ} / \mathrm{ADt}$ (546 to $614 \mathrm{kgce} / \mathrm{ADt}$ ) and electricity use to be $700 \mathrm{kWh} / \mathrm{ADt}^{55}$

\subsubsection{Mechanical Pulping}

Energy use in mechanical pulping is determined by the wood type used and the "freeness" of the pulp. The "freeness" is an expression for the fiber quality and water retention. Hence, energy use may vary widely on the basis of the desired pulp quality given a specific wood type used.

There are several types of processes that can be used for mechanical pulping, i.e. groundwood (GW), thermo-mechanical pulping (TMP) and chemo-thermo-mechanical pulping (CTMP). The best practice assumes TMP. TMP allows the recovery of heat from

\footnotetext{
${ }^{54}$ Francis, D.W., M.T. Towers and T.C. Browne. 2002. Energy Cost Reduction in the Pulp and Paper Industry - An Energy Benchmarking Perspective. NRCan, Ottawa, ON, Canada.

55 IPPC, 2001. Reference Document on Best Available Techniques in the Pulp and Paper Industries. Integrated Pollution Prevention \& Control. European Commission, Brussels/Sevilla, 2001.
} 
the process in the form of hot water and steam, as only a fraction of the energy is actually used to separate the fibers. TMP allows the recovery of $60-65 \%$ of the heat generated in the process (45\% as steam, $20 \%$ as hot water). However, a TMP mill consumes more power than a groundwood mill. The best practice integrated TMP newsprint mill consists of a pressurized TMP mill consuming about $2190 \mathrm{kWh} / \mathrm{ADt}$ and generating $1.33 \mathrm{GJ} / \mathrm{ADt}$ (45 kgce/ADt) of heat. For an non-integrated pulp mill electricity use is estimated at 2420 $\mathrm{kWh} / \mathrm{ADt}$ with generation of $5.5 \mathrm{GJ} / \mathrm{ADt}$ of steam. ${ }^{56,57}$

\subsubsection{Fiber Recovery}

Fiber recycling is an important option for reducing pulping energy use. China also imports paper from other countries (notably the US and Europe) to provide its fiber needs. Recycled fiber has become a global market in which China is an important consumer. The used fibers are pulped and (optionally) de-inked before being fed to stock preparation for the paper machine. Based on the performance of Swedish mills, the best practice is estimated to be $0.3 \mathrm{GJ} / \mathrm{ADt}$ (10 kgce/ADt) use of steam and electricity use of $330 \mathrm{kWh} / \mathrm{ADt}^{58}$

\subsubsection{Papermaking}

Energy use in the paper machine is determined by the specific grade of paper to be produced and the fiber quality (e.g. water retention) in the pulp. Moreover, not all energyefficient technologies are suitable for all paper grades. The best practice values assume that an effective control system is in place, long nip (or shoe) press is being used (not suitable for tissue mills), use of efficient motors, condensate recovery, a closed hood for heat recovery, as well as integration of the various steam and hot water flows in the mill. Note that small scale mills may have a steam consumption that is $10-25 \%$ higher and an electricity consumption that is $5-20 \%$ higher than the figures presented in Table 2.4.1. ${ }^{59}$

\subsubsection{Integrated Pulp and Paper Mills}

Integrated mills can be more energy efficient than stand-alone mills, as no drying energy is needed for the intermediate drying of the pulp. This will result in energy savings at the pulp mill. Furthermore, process integration of the different processes may result in a further optimization of the steam use on site. Finally, while stand-alone pulp mills may have excess steam that cannot be used (due to black/green liquor recovery or from heat recovery of the TMP), an integrated mill can use this excess heat to serve the additional heat use of the paper machine. Tables 2.4.5 and 2.4.6 summarize the best practice final and primary energy intensity, respectively, of various integrated mill types.

\footnotetext{
${ }^{56}$ Francis, D.W., M.T. Towers and T.C. Browne. 2002. Energy Cost Reduction in the Pulp and Paper Industry - An Energy Benchmarking Perspective. NRCan, Ottawa, ON, Canada.

${ }^{57}$ IPPC, 2001. Reference Document on Best Available Techniques in the Pulp and Paper Industries. Integrated Pollution Prevention \& Control. European Commission, Brussels/Sevilla, 2001.

${ }^{58}$ Francis, D.W., M.T. Towers and T.C. Browne. 2002. Energy Cost Reduction in the Pulp and Paper Industry - An Energy Benchmarking Perspective. NRCan, Ottawa, ON, Canada.

${ }^{59}$ IPPC, 2001. Reference Document on Best Available Techniques in the Pulp and Paper Industries. Integrated Pollution Prevention \& Control. European Commission, Brussels/Sevilla, 2001.
} 
Table 2.4.5. World Best Practice Final Energy Intensity Values for Integrated Pulp and Paper Mills (values are per air dried metric tons). ${ }^{60,61}$

\begin{tabular}{|c|c|c|c|c|c|c|c|}
\hline \multirow{2}{*}{$\begin{array}{l}\text { Raw } \\
\text { Material }\end{array}$} & \multirow[t]{2}{*}{ Product } & \multirow[t]{2}{*}{ Process } & \multicolumn{2}{|c|}{ Fuel Use for Steam } & \multirow{2}{*}{$\begin{array}{l}\text { Electricity } \\
\text { kWh/ADt }\end{array}$} & \multicolumn{2}{|c|}{ Total } \\
\hline & & & GJ/ADt & kgce/ADt & & GJ/ADt & kgce/ADt \\
\hline \multirow[t]{7}{*}{ Wood } & Bleached Uncoated Fine & Kraft & 14 & 478 & 1200 & 18.3 & 625 \\
\hline & $\begin{array}{l}\text { Kraftliner (unbleached) } \\
\text { and Bag Paper }\end{array}$ & Kraft & 14 & 478 & 1000 & 17.6 & 601 \\
\hline & Bleached Coated Fine & Sulfite & 17 & 580 & 1500 & 22.4 & 765 \\
\hline & Bleached Uncoated Fine & Sulfite & 18 & 614 & 1200 & 22.3 & 762 \\
\hline & Newsprint & TMP & -1.3 & -44 & 2200 & 6.6 & 226 \\
\hline & Magazine Paper & TMP & -0.3 & -10 & 2100 & 7.3 & 248 \\
\hline & Board & $50 \%$ TMP & 3.5 & 119 & 2300 & 11.8 & 402 \\
\hline \multirow{3}{*}{$\begin{array}{l}\text { Recovered } \\
\text { Paper }\end{array}$} & Board (no de-inking) & & 8 & 273 & 900 & 11.2 & 384 \\
\hline & Newsprint (de-inked) & & 4 & 137 & 1000 & 7.6 & 259 \\
\hline & Tissue (de-inked) & & 7 & 239 & 1200 & 11.3 & 386 \\
\hline
\end{tabular}

Table 2.4.6. World Best Practice Primary Energy Intensity Values for Integrated Pulp and Paper Mills (values are per air dried metric tons). ${ }^{62,63}$

\begin{tabular}{|c|c|c|c|c|c|c|c|}
\hline \multirow{2}{*}{$\begin{array}{l}\text { Raw } \\
\text { Material }\end{array}$} & \multirow[t]{2}{*}{ Product } & \multirow[t]{2}{*}{ Process } & \multicolumn{2}{|c|}{ Fuel Use for Steam } & \multirow{2}{*}{$\begin{array}{l}\text { Electricity } \\
\text { kWh/ADt }\end{array}$} & \multicolumn{2}{|c|}{ Total } \\
\hline & & & GJ/ADt & kgce/ADt & & GJ/ADt & kgce/ADt \\
\hline \multirow[t]{7}{*}{ Wood } & Bleached Uncoated Fine & Kraft & 14 & 478 & 3636 & 27.1 & 925 \\
\hline & $\begin{array}{l}\text { Kraftliner (unbleached) } \\
\text { and Bag Paper }\end{array}$ & Kraft & 14 & 478 & 3030 & 24.9 & 850 \\
\hline & Bleached Coated Fine & Sulfite & 14 & 478 & 3030 & 24.9 & 850 \\
\hline & Bleached Uncoated Fine & Sulfite & 17 & 580 & 4545 & 33.4 & 1139 \\
\hline & Newsprint & TMP & 18 & 614 & 3636 & 31.1 & 1061 \\
\hline & Magazine Paper & TMP & -1.3 & -44 & 6667 & 22.7 & 775 \\
\hline & Board & $50 \%$ TMP & -0.3 & -10 & 6364 & 22.6 & 772 \\
\hline \multirow{3}{*}{$\begin{array}{l}\text { Recovered } \\
\text { Paper }\end{array}$} & Board (no de-inking) & & 3.5 & 119 & 6970 & 28.6 & 976 \\
\hline & Newsprint (de-inked) & & 8 & 273 & 2727 & 17.8 & 608 \\
\hline & Tissue (de-inked) & & 4 & 137 & 3030 & 14.9 & 509 \\
\hline
\end{tabular}

Note: Primary energy includes electricity generation, transmission, and distribution losses of $67 \%$.

${ }^{60}$ IPPC, 2001. Reference Document on Best Available Techniques in the Pulp and Paper Industries. Integrated Pollution Prevention \& Control. European Commission, Brussels/Sevilla, 2001.

${ }^{61}$ Francis, D.W., M.T. Towers and T.C. Browne. 2002. Energy Cost Reduction in the Pulp and Paper Industry - An Energy Benchmarking Perspective. NRCan, Ottawa, ON, Canada.

${ }^{62}$ IPPC, 2001. Reference Document on Best Available Techniques in the Pulp and Paper Industries. Integrated Pollution Prevention \& Control. European Commission, Brussels/Sevilla, 2001.

${ }^{63}$ Francis, D.W., M.T. Towers and T.C. Browne. 2002. Energy Cost Reduction in the Pulp and Paper Industry - An Energy Benchmarking Perspective. NRCan, Ottawa, ON, Canada. 


\subsection{Ammonia}

Ammonia $\left(\mathrm{NH}_{3}\right)$ manufacture is the most energy-intensive production step in the production of nitrogenous fertilizers. Ammonia is made by the Haber-Bosch process, combining nitrogen and hydrogen. The hydrogen is most often produced from synthesis gas. Synthesis gas can be produced from natural gas, oil (residues), coal or any hydrocarbon feedstock. Natural gas is the preferred feedstock due to the high hydrogen content. Today, over $80 \%$ of the world ammonia capacity is produced from natural gas. However, China is one of the largest ammonia producers in the world and in 2004, 70.3\% of the feedstock for ammonia production in China was coal, 22.7\% was natural gas, and $7 \%$ was oil. ${ }^{64}$

The energy intensity of anhydrous ammonia production is dependent on feedstock, processes, and technology. Natural gas is the most energy-efficient feedstock, followed by heavy oil, which requires an average 30\% more input energy per t of output, and coal, which requires an average $70 \%$ more input energy per ton output. ${ }^{65}$ Within each of these feedstocks, the most common production processes are steam reforming of natural gas, partial oxidization of heavy fuel oil, gasification of coal, and electrolysis.

The minimum theoretical energy required for ammonia production depends on the composition of the natural gas feedstock, but it can be as low as $19.2 \mathrm{GJ} / \mathrm{t}$ ammonia or 23.3 GJ/t nitrogen (both in lower heating value, LHV). ${ }^{66}$ The current best practice will depend strongly on the feedstock. The best practice for natural gas and coal feedstocks are provided below. Table 2.5.1 summarizes best practice final energy intensity values for specific ammonia production processes. Since electricity use in ammonia production is negligible, primary energy intensity values are assumed to be the same as final energy intensity values.

Table 2.5.1. World Best Practice Final Energy Intensity Values for Ammonia Production (values are per $t$ ammonia and $t$ nitrogen)

\begin{tabular}{|l|c|c|c|c|}
\hline \multirow{2}{*}{ Feedstock } & \multicolumn{4}{c|}{ Energy Intensity } \\
\cline { 2 - 5 } & $\mathrm{GJ}^{*} \mathrm{t} \mathrm{NH}_{3}$ & $\mathrm{GJ} / \mathrm{t} \mathrm{N}$ & $\mathrm{kgce} / \mathrm{NH}_{3}$ & $\mathrm{kgce} / \mathrm{t} \mathrm{N}$ \\
\hline Natural gas steam reforming & 28 & 34 & 956 & 1160 \\
\hline Coal $^{67}$ & 34.8 & 42.3 & 1188 & 1444 \\
\hline
\end{tabular}

\subsubsection{Natural Gas Steam Reforming}

In 1998 the most energy-efficient recorded ammonia production from natural gas required $28 \mathrm{GJ} / \mathrm{t}$ (1160 kgce/t) $\mathrm{NH}_{3}$ or $34 \mathrm{GJ} / \mathrm{t}$ (956 kgce/t) N. Limited power imports are

\footnotetext{
${ }^{64}$ China Chemical Technology Industry Association, 2006

65 European Fertilizer Manufacturers Association, 1997. Production of Ammonia: Description of Production Processes, Brussels, Belgium.

${ }^{66}$ Ramirez, C.A., Worrell, E., 2006. "Feeding fossil fuels to the soil; an analysis of energy embedded and technological learning in the fertilizer industry,” Resource Conservation \& Recycling 46 (2006): 75-93.

67 Sinopec (2004) “2004 Parameter and Data," Beijing: Sinopec, p.5-51; most Chinese ammonia is made from heavy oil and coal, which is much less energy-efficient than natural gas.
} 
necessary, assuming the ammonia loop compressor uses a steam turbine, using internally generated steam.

Various suppliers offer process designs that can attain such an efficiency level. These processes are characterized by a highly integrated primary and secondary reformer (e.g. the KRES system offered by $\mathrm{KBR}$ ), $\mathrm{CO}_{2}$ removal using a physical absorption process (e.g. selexol), low-pressure ammonia synthesis loop, high-efficiency catalysts, as well as (membrane) methane (from the methanator) and hydrogen recovery.

\subsubsection{Coal}

The best practice ammonia plant using coal as feedstock would use a coal gasifier to convert the coal to synthesis gas. Most coal gasifier-based ammonia plants are constructed in China.

The most recent plants use Shell or ChevronTexaco gasification technology, e.g. CNTIC Nanjing Chemical's ammonia plant (start-up in 2003), Jilin and Haolianghe (2004) and Sinopec's plants in Hubei, Anqing, and Dongtinq (2006). The processes consist of a modern entrained bed gasifier, selexol gas cleanup and a low-pressure ammonia synthesis loop. Part of the $\mathrm{CO}_{2}$ is used for the production of urea in sites that produce ammonia and urea.

Based on the performance of the ammonia plant in Coffeyville (Kansas, US) that uses petroleum coke, the best practice specific energy consumption is estimated to be 34.8 GJ/t (1188 kgce/t) ammonia. 


\subsection{Ethylene}

Ethylene is produced from various hydrocarbon feedstocks with the steam cracking process. Along with ethylene, other high value products such as propylene, butadiene and aromatics are co-produced in the process. In an absolute sense, steam cracking is the most energy-intensive process in the petrochemical industry with an estimated worldwide energy use (excluding feedstock use) of approximately $2.8 \mathrm{EJ}$. $^{68}$ The dominant feedstock for worldwide ethylene production is naphtha (55\%), followed by ethane (30\%), liquefied petroleum gas (10\%) and gas oil (5\%). ${ }^{69}$ Regional differences are substantial with ethane cracking being the dominant technology in the U.S. and naphtha cracking the dominant technology in most other world regions, including China. ${ }^{70}$

\subsubsection{Naphtha and Ethane}

Tables 2.6.1 and 2.6.2 provide best practice final and primary energy intensity values, respectively, for naphtha and ethane cracking, the two most widely used feedstocks in conventional ethylene production. Energy use of the processes is allocated to all High Value Chemicals (HVC) to allow a fair comparison between various technologies. This is a method also followed by Solomon Associates Ltd., a company performing international benchmarks for the petrochemical industry. ${ }^{71}$ Allocating all energy use to ethylene alone would yield confusing results, because the ethylene yield differs widely per process. ${ }^{72}$ Based on a survey of European steam crackers, an actual energy use of 14 to $22 \mathrm{GJ} / \mathrm{t}$ (478 to $751 \mathrm{kgce} / \mathrm{t}$ ) HVCs is found for naphtha crackers and 12.5 to $21.0 \mathrm{GJ} / \mathrm{t}$ (427 to 717 kgce/t) HVCs for ethane crackers . ${ }^{73}$

\footnotetext{
${ }^{68}$ Neelis, M.L., Patel, M.K., Bach, P.W. and Haije, W.G., 2005. Analysis of energy use and carbon losses in the chemical and refinery industries. Report ECN-I-05-008, Energy Research Centre of the Netherlands, Petten, the Netherlands.

${ }^{69}$ Ren, T., Patel, M., and Blok, K., 2006. "Olefins from conventional and heavy feedstocks: Energy use in steam cracking and alternative processes,” Energy 31 (2006), pp. 425-451.

${ }^{70}$ From international energy statistics (International Energy Agency, 2005. Extended energy balances of Non-OECD countries., Paris, France: IEA), we can conclude that in China, mainly naphtha cracking is applied, because approximately $90 \%$ of the oil feedstock delivery to the chemical industry was naphtha in 2003.

${ }^{71}$ Worrell, E., Phylipsen, D., Einstein, D. and Martin, N., 2000. Energy use and energy intensity in the US chemical industry. Berkeley, California: Lawrence Berkeley National Laboratory, LBNL-44314.

${ }^{72}$ Phylipsen, G.J.M., 2000. "A methodology for international comparisons of the energy efficiency in the petrochemical industry," Chapter 3 in: International Comparisons and National Commitments, PhD thesis, Utrecht University, Utrecht, the Netherlands.

${ }^{73}$ Institute for Prospective Technological Studies, 2003. Reference document on best available technologies in the large volume organic chemical industry, Seville, Spain: European Commission, Joint Research Centre, IPTS.
} 
Table 2.6.1. World Best Practice Final Energy Intensity Values for Ethane and Naphtha Cracking (values are per $t$ high value chemicals).

\begin{tabular}{|c|c|c|c|c|c|c|c|c|c|c|c|c|}
\hline \multirow[b]{2}{*}{ Unit process } & \multicolumn{6}{|c|}{ Ethane } & \multicolumn{6}{|c|}{ Naphtha } \\
\hline & $\begin{array}{l}\text { GJ/t } \\
\text { HVC }\end{array}$ & $\begin{array}{c}\mathrm{kWh} / \mathrm{t} \\
\mathrm{HVC}\end{array}$ & $\begin{array}{c}\text { Total } \\
\text { GJ/t HVC } \\
\end{array}$ & $\begin{array}{l}\text { kgce/t } \\
\text { HVC }\end{array}$ & $\begin{array}{c}\mathrm{kWh} / \mathrm{t} \\
\mathrm{HVC}\end{array}$ & $\begin{array}{c}\text { Total } \\
\text { kgce/t HVC }\end{array}$ & $\begin{array}{l}\text { GJ/t } \\
\text { HVC }\end{array}$ & $\begin{array}{l}\mathrm{kWh} / \mathrm{t} \\
\mathrm{HVC}\end{array}$ & $\begin{array}{c}\text { Total } \\
\text { GJ/t HVC }\end{array}$ & $\begin{array}{c}\text { kgce/t } \\
\text { HVC }\end{array}$ & $\begin{array}{l}\mathrm{kWh} / \mathrm{t} \\
\mathrm{HVC}\end{array}$ & $\begin{array}{c}\text { Total kgce/t } \\
\text { HVC }\end{array}$ \\
\hline Cracker & 4.9 & 278 & 5.9 & 184 & 278 & 219 & 6.5 & & 6.5 & 244 & & 244 \\
\hline Heat of reaction & 2.6 & & & 90 & & & 2.0 & & 2.0 & 75 & & 75 \\
\hline $\begin{array}{r}\text { Steam, heating and } \\
\text { losses }\end{array}$ & 2.8 & & & 94 & & & 4.5 & & 4.5 & 169 & & 169 \\
\hline $\begin{array}{l}\text { Fractionation and } \\
\text { compression }\end{array}$ & 2.8 & & 2.8 & 86 & & 86 & 1.5 & & 1.5 & 56 & & 56 \\
\hline Separation & 3.9 & & 3.9 & 122 & & 122 & 2.0 & & 2.0 & 75 & & 75 \\
\hline Total & 11.5 & & 12.5 & 392 & & 427 & 10.0 & 278 & 11.0 & 375 & 278 & 409 \\
\hline
\end{tabular}

Table 2.6.2. World Best Practice Primary Energy Intensity Values for Ethane and Naphtha Cracking (values are per $t$ high value chemicals).

\begin{tabular}{|c|c|c|c|c|c|c|c|c|c|c|c|c|}
\hline \multirow[b]{2}{*}{ Unit process } & \multicolumn{6}{|c|}{ Ethane } & \multicolumn{6}{|c|}{ Naphtha } \\
\hline & $\begin{array}{l}\mathrm{GJ} / \mathrm{t} \\
\mathrm{HVC}\end{array}$ & $\begin{array}{c}\mathrm{kWh} / \mathrm{t} \\
\mathrm{HVC}\end{array}$ & $\begin{array}{c}\text { Total } \\
\text { GJ/t HVC }\end{array}$ & $\begin{array}{l}\text { kgce/t } \\
\text { HVC }\end{array}$ & $\begin{array}{l}\text { kWh/t } \\
\text { HVC }\end{array}$ & $\begin{array}{c}\text { Total } \\
\text { kgce/t HVC }\end{array}$ & $\begin{array}{l}\mathrm{GJ} / \mathrm{t} \\
\mathrm{HVC}\end{array}$ & $\begin{array}{l}\mathrm{kWh} / \mathrm{t} \\
\mathrm{HVC}\end{array}$ & $\begin{array}{c}\text { Total } \\
\text { GJ/t HVC }\end{array}$ & $\begin{array}{l}\text { kgce/t } \\
\text { HVC }\end{array}$ & $\begin{array}{l}\text { kWh/t } \\
\text { HVC }\end{array}$ & $\begin{array}{c}\text { Total kgce/t } \\
\text { HVC }\end{array}$ \\
\hline Cracker & 4.9 & 842 & 7.9 & 184 & 842 & 288 & 6.5 & & 6.5 & 244 & & 244 \\
\hline Heat of reaction & 2.6 & & & 90 & & & 2.0 & & 2.0 & 75 & & 75 \\
\hline $\begin{array}{r}\text { Steam, heating and } \\
\text { losses }\end{array}$ & 2.8 & & & 94 & & & 4.5 & & 4.5 & 169 & & 169 \\
\hline $\begin{array}{l}\text { Fractionation and } \\
\text { compression }\end{array}$ & 2.8 & & 2.8 & 86 & & 86 & 1.5 & & 1.5 & 56 & & 56 \\
\hline Separation & 3.9 & & 3.9 & 122 & & 122 & 2.0 & & 2.0 & 75 & & 75 \\
\hline Total & 11.5 & & 14.5 & 392 & & 496 & 10.0 & 842 & 13.0 & 375 & 842 & 478 \\
\hline
\end{tabular}

Note: Primary energy includes electricity generation, transmission, and distribution losses of $67 \%$. 
Although difficult, because of the intensive energy integration applied in a steam cracker, it is possible to roughly divide the total energy use into the various sections of the cracker. ${ }^{74}$ As most processes in the chemical industry, steam cracking can be regarded as a combination of a reaction section, where the feedstock is converted to the desired products and a separation section, where the various products are separated into chemical grade sellable commodities. In the cracker, naphtha or ethane are cracked at high temperatures (750-900 ${ }^{\circ} \mathrm{C}$ ) and quenched to lower temperatures to stop the reaction. In the quench, high-pressure steam is generated that is used for driving compressors etc. In the separation section, first the heavy fraction is condensed (the hot separation train, only for naphtha and gas oil cracking) and the gaseous fraction is compressed. In the cold separation, the various lighter products (ethylene, propylene, and butadiene) are separated using cryogenic distillation. The exact process layout depends heavily on the feedstock processes. Typical yields of the various products are given in Table 2.6.3.

The conversions in the cracker are endothermic and the heat of reaction is the minimal amount of energy required to convert the feedstock to the products (both at standard conditions of 1 bar and $25^{\circ} \mathrm{C}$ ) and is equivalent to approximately $20-25 \%$ of the process energy. The separation is responsible for $20-30 \%$ of the energy consumption with the remaining energy being consumed in the cracker (e.g. the heat embodied in the flue gases of the cracker furnace) and in the compression section.

\section{Table 2.6.3. Yields (\%) for Ethane and Naphtha Cracking ${ }^{75}$}

\begin{tabular}{|l|c|c|}
\hline Product & Ethane & Naphtha \\
\hline Ethylene - HVC & $80-84$ & $29-34$ (30\% typical) \\
\hline Propylene - HVC & $1-1.6$ & $13-16$ \\
\hline Butadiene - HVC & $1-1.4$ & $4-5$ \\
\hline Aromatics and C4+-HVC & $2-3$ & $10-16$ \\
\hline Total yield of HVC's & 82 (typical) & 55 (typical) \\
\hline Methane yield & 4.2 & $13-14$ \\
\hline Hydrogen yield & 4.3 & 1 \\
\hline Backflows to refineries & 0 & $9-10$ \\
\hline Losses & $1-2$ & $1-2$ \\
\hline
\end{tabular}

A recent report provides an excellent overview of state-of-the-art naphtha cracking technologies based on information from technology suppliers as well as the various furnace and separation related features offered by the licensors. ${ }^{76}$ An overview of the ethylene yields and specific energy consumption values are provided in Table 2.6.4.

\footnotetext{
${ }^{74}$ The figures should be considered only indicative, because they were taken from various sources partly applying different system boundaries and assumptions.

${ }^{75}$ Ren, T., Patel, M., and Blok, K., 2006. "Olefins from conventional and heavy feedstocks: Energy use in steam cracking and alternative processes,” Energy 31 (2006), pp. 425-451.

${ }^{76}$ Ren, T., Patel, M., and Blok, K., 2006. "Olefins from conventional and heavy feedstocks: Energy use in steam cracking and alternative processes,” Energy 31 (2006), pp. 425-451.
} 
Table 2.6.4. State-of the-Art Specific Final Energy Use Values for Naphtha Steam per licensor. ${ }^{77}$

\begin{tabular}{|c|c|c|c|c|c|}
\hline & $\begin{array}{l}\text { Technip - } \\
\text { Coflexip }\end{array}$ & $\begin{array}{c}\text { ABB } \\
\text { Lummus }\end{array}$ & $\begin{array}{l}\text { Linde } \\
\text { AG }\end{array}$ & $\begin{array}{l}\text { Stone \& } \\
\text { Webster }\end{array}$ & $\begin{array}{c}\text { Kellog Brown } \\
\text { \& Root }\end{array}$ \\
\hline $\begin{array}{l}\text { Ethylene } \\
\text { Yield wt. \% }\end{array}$ & $35 \%$ & $34.4 \%$ & $35 \%$ & $\begin{array}{l}\text { No data } \\
\text { found }\end{array}$ & $38 \%$ \\
\hline $\begin{array}{l}\text { Energy use } \\
\text { GJ/t ethylene }\end{array}$ & $\begin{array}{c}\text { Best: } 18.8-20 \\
\text { Typical: } 21.6 \text { - } \\
25.2\end{array}$ & $\begin{array}{l}\text { Best: } 18 \\
\text { (w/gas } \\
\text { turbine) } \\
\text { Typical: } 21\end{array}$ & Best: 21 & $20-25$ & No data found \\
\hline
\end{tabular}

If a yield factor of 1.83 ton HVCs/t ethylene is applied to the energy consumption figures presented in Table 2.6.4., then the current best-practice naphtha crackers offered by licensors have a specific energy consumption of 11 to $14 \mathrm{GJ} / \mathrm{t}$ (375 to $478 \mathrm{kgce} / \mathrm{t}$ ). These best-practice naphtha crackers focus on the design optimization of the furnace coils to improve heat transfer, minimize coking and maximize the yield of olefins. In the separation process, front-end demethanization can reduce refrigeration energy needs. The gas turbine technology also mentioned in Table 2.6.4 refers to a process option where a steam cracker is operated integrated with a gas turbine, producing steam and electricity. The hot off-gases from the turbine are used for feedstock heating. This option could save $3 \mathrm{GJ} / \mathrm{t}$ (102 kgce/t) ethylene, but this option has not been used widely so far. No comparable detailed data could be found on best-practice ethane cracking. Therefore, the lowest value found from the literature (12.5 GJ/t HVCs or 427 kgce/t HVCs) is regarded as the best practice ethane cracking technology.

\subsubsection{Other Feedstocks and Emerging Technologies}

Besides naphtha and ethane, also other feedstocks are applied in steam cracking such as LPG (mixtures of propane and butane) and gas oil (heavier feedstock compared to naphtha). Generally speaking, the specific energy consumption of gas oil crackers is somewhat higher compared to naphtha crackers (e.g. a range of 18 to $23 \mathrm{GJ} / \mathrm{t}$ HVCs or 614 to 785 kgce/t HVCs). ${ }^{78}$ LPG has process characteristics between ethane and naphtha cracking.

Two recent publications provide an excellent overview of wide variety of possible ethylene and propylene technologies from conventional and heavy feedstocks, including advanced naphtha cracking technologies and from natural gas. ${ }^{79,} 80$ They conclude that

\footnotetext{
${ }^{77}$ Ren, T., Patel, M., and Blok, K., 2006. "Olefins from conventional and heavy feedstocks: Energy use in steam cracking and alternative processes,” Energy 31 (2006), pp. 425-451.

${ }^{78}$ Institute for Prospective Technological Studies, 2003. Reference document on best available technologies in the large volume organic chemical industry, Seville, Spain: European Commission, Joint Research Centre, IPTS.

${ }^{79}$ Ren, T., Patel M., and Blok, K., 2005. Steam Cracking and Natural Gas-to-Olefins: A Comparison of Energy Use, $\mathrm{CO}_{2}$ Emissions and Economics. 2005 Spring National Meeting of American Institute of Chemical Engineers (AIChE), Atlanta, USA.

${ }^{80}$ Ren, T., Patel, M., and Blok, K., 2006. "Olefins from conventional and heavy feedstocks: Energy use in steam cracking and alternative processes,” Energy 31 (2006), pp. 425-451.
} 
all possible routes from natural gas via methanol production consume about twice the amount of energy as in conventional steam cracking. Of the processes starting from conventional steam cracking, some have very low specific energy consumption values (8 to $10 \mathrm{GJ} / \mathrm{t}$ HVCs or 273 to $341 \mathrm{kgce} / \mathrm{t} \mathrm{HVCs}$ ), but these technologies (e.g. shockwave reactors) are still in the laboratory phase. Catalytic cracking and hydro-pyrolisis of naphtha also offer lower specific energy consumption figures (10 to $13 \mathrm{GJ} / \mathrm{t}$ or 341 to 444 kgce/t), but these processes are either not commercially available yet (catalytic cracking is in the pilot plant stage) or is not offered by major licensors.

\section{Summary and Next Steps}

"World best practice" energy intensity values, representing the most energy-efficient processes that are in commercial use in at least one location worldwide, have been provided in this report for the production of iron and steel, aluminium, cement, pulp and paper, ammonia, and ethylene. Energy intensity is expressed in energy use per physical unit of output for each of these commodities; most commonly these are expressed in metric tonnes $(\mathrm{t})$. The energy intensity values are provided by major energy-consuming processes for each industrial sector to allow comparisons at the process level. Energy values are provided for final energy, defined as the energy used at the production facility as well as for primary energy, defined as the energy used at the production facility as well as the energy used to produce the electricity consumed at the facility.

The "best practice" figures for energy consumption provided in this report should be considered as indicative, as these may depend strongly on the material inputs. For example, energy consumption in steel, cement, and paper production depends strongly on the amount of primary materials (e.g. iron ore, wood/straw) versus secondary materials (e.g. scrap, waste paper). These may vary over time depending on the availability, costs, characteristics and quality, as well as product type and quality. For sectors where such variety exists it may be worthwhile to develop a "benchmarking" tool to calculate the "best practice" energy consumption for a specific plant configuration and materials used and produced. In such a tool, the user could input the production characteristics and calculate "best practice" energy use and intensity for a specific plant and its production variables. Also, such a tool could help plants to identify the key areas in a plant for energy efficiency improvement.

\section{Acknowledgments}

This work was funded by the Energy Foundation through the U.S. Department of Energy Contract No. No. DE-AC02-05CH11231. This report does not necessarily reflect the opinion of the Energy Foundation. We wish to thank Dolf Gielen of the International Energy Agency and Klaas Jan Kramer for their helpful comments on a previous draft. We also thank Pasi Rousu for providing additional information on the Chempolis process, David Fridley of LBNL for his assistance on the section on ethylene production, and Nathaniel Aden for his contribution to previous drafts. Despite their efforts, any remaining errors remain the sole responsibility of the authors. 